\title{
Impact of Plant Spacing and Weed Control Treatments on Yield, Quality of Soybean (Glycine Max L.) and Associated Weeds Characters under Middle Egypt Conditions
}

\author{
${ }^{*}$ Morsy, A.S.M. ${ }^{1}$ and M. M. Tantawy ${ }^{2}$ \\ ${ }^{1}$ Department of Agronomy, Faculty of Agriculture and Natural Resources, Aswan, Uni- \\ versity, Aswan 81528, Egypt. \\ ${ }^{2}$ Plant Protection Department, Faculty of Agriculture, Minia University, Minia, Egypt. \\ "Corresponding author: drahmed1122@yahoo.com
}

Received on: $22 / 3 / 2018$

Accepted for publication on: 11/4/2018

\begin{abstract}
The present study was carried out on soybean var. Giza 111 atthe Experimental Farm of Faculty of Agriculture, El-Minia University during the summer seasons of 2015 and 2016, to study the impact of plant spacing and weed control treatments on weed control, yield and quality of soybean. The treatments include rows and plant spacing (density) as $\mathrm{P}_{1}: 60 \times 4 \mathrm{~cm}\left(175000\right.$ plant fed $\left.^{-1}\right), \mathrm{P}_{2}: 60 \times 5 \mathrm{~cm}$

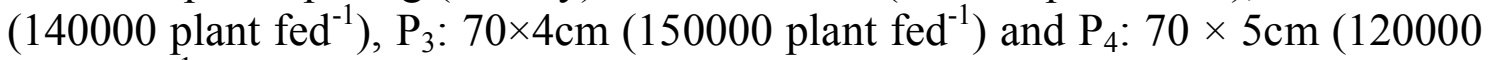
plant $\left.\mathrm{fed}^{-1}\right)$ and 10 weed control treatments $\left(\mathrm{W}_{1}\right.$ : Gesagard $50 \% \mathrm{FW}$ at $1 \mathrm{~L}^{-} \mathrm{fed}^{-}$ ${ }^{1}, \mathrm{~W}_{2}$ : Fusilade super $12.5 \% \mathrm{EC}$ at $1 \mathrm{~L} \mathrm{fed}^{-1}, \mathrm{~W}_{3}$ : Gesagard $50 \% \mathrm{FW}+$ Fusilade super $12.5 \% \mathrm{EC}, \mathrm{W}_{4}$ :Stomp $50 \% \mathrm{EC}$ at $1.7 \mathrm{~L} \mathrm{fed}^{-1}, \mathrm{~W}_{5}$ : Stomp $50 \% \mathrm{EC}+$ Selectsuper $12.5 \% \mathrm{EC}$ at $1 \mathrm{~L} \mathrm{fed}^{-1}, \mathrm{~W}_{6}$ : Select-super $12.5 \% \mathrm{EC}, \mathrm{W}_{7}$ : Stomp $12.5 \% \mathrm{EC}+$ one hand hoeing, $\mathrm{W}_{8}$ : hand hoeing twice, $\mathrm{W}_{9}$ : unweeded check and $\mathrm{W}_{10}$ : weed free for whole seasons. This study was carried out in a strip-plot design with three replications. Results showed that increasing of soybean plant density by sowing in the narrow ridge $(60 \mathrm{~cm})$ and plant space $(4 \mathrm{~cm}$ between hills) caused a significant reduction in fresh and dry weight of weeds at 60 days after planting (DAP), compared to wider plant spacing in both seasons. The narrow spacing $60 \times 4 \mathrm{~cm}$ led to a reduction in dry weight of total weeds by $26.62 \%$ and $22.90 \%$ and increased soybean seed yield by $5.31 \%$ and $4.92 \%$ in 2015 and 2016 seasons, respectively. All weed control practices reduced the fresh and dry weight of total weeds, compared to the unweeded check in both seasons. Yield of seeds in unweeded check plots was decreased were about 43.18 and $42.69 \%$ due to about 3.5 and 3.3 ton fed $^{-1}$ fresh weight of total weeds in 2015 and 2016 seasons, respectively, compared to weed free for whole season. Protein and oil $\%$ of soybean seeds were decreased by $(10.56$ and $10.60 \%)$ and $(18.23$ and $18.05 \%)$ in $1^{\text {st }}$ and $2^{\text {nd }}$ seasons, respectively due to the weed interference. The interaction effect between plant spacing, $60 \times 4 \mathrm{~cm}\left(\mathrm{P}_{1}\right)$ and weed free followed plant spacing $\mathrm{P}_{1}$ and weed control by Stomp 50\%EC + one hand hoeing $\left(\mathrm{W}_{7}\right)$ gave the best weed control efficiency (WCE) 78.9 and $81.0 \%$ in 2015 and 2016 seasons, respectively as well as superior in seed yield of soybean and net return.
\end{abstract}

Keywords: Soybean, plant spacing, herbicides, weed control treatments, Seed quality, WCE, WI.

\section{Introduction}

Soybean (Glycine $\max$ L.) is one of the most important summer leguminous crops, extensively successful in many provinces in Egypt and worldwide. Soybean is known as 
"Golden bean" and miracle or wonder crop of $21^{\text {th }}$ century. Chemical analysis showed that soybean seed contains almost $20 \%$ oil, $40 \%$ protein, $30 \%$ carbohydrates, $10 \%$ total sugar and $5 \%$ ash (Gulluoglu et al., 2017). It is very rich in mineral, vitamins, riboflavin, thiamins, iron, particularly calcium, phosphorus, salts and essential fatty acids (Acikgz et al., 2009). Therefore, Soybean is considered an excellent source of food for human and animal consumption. Soybean hasa versatile and fascinating innumerable possibilities not only in agriculture (i.e, fixes atmospheric $\mathrm{N}$ from 20 to $25 \mathrm{~kg} \mathrm{fed}^{-1}$ through root nodules and adds approximately 0.7 ton $\mathrm{fed}^{-1}$ organic matter through leaf fall (Kanase et al., 2006) but also in the industry. The world harvest of soybean is more than $50 \%$ of the total world oil seed production. Soyflour is extensively used in the industry of insecticides, disinfectants, and also in enrichment of media used for testing antibiotics. Soybean reduces the risk of cancers breast and prostate possibly due to the presence of isoflavone (Cassileth and Vickers, 2003).

In Egypt, the area of soybean in 2015 was 33896 fed, produced 46671 ton, with an average productivity of 1.377 ton $\mathrm{fed}^{-1}$ (Agriculture Statistics, 2015).

Application of proper agronomic methods is one of the important factors for increasing the yield of soybean per unit area. This includes management of soybean plant spacing and densities, which is one of the important agronomic practices influencing crop growth and productivity (Caliskan et al., 2007; El-Far et al., 2016; Asmaa et al., 2017; Gul- luoglu et al., 2017 and Matsuo et al., 2018). Plant density plays an important role in the competitive balance between weeds and soybean. Suitable plant spacing causes development of branches and increases the node number and pod plant ${ }^{-1}$ (Saitoh, 2011; El-Far et al., 2016 and Gulluoglu et al., 2017). Narrow row spacing is known to suppress weed growth, increased root activity and vertical distribution of light by closing crop canopy earlier than wider row spacing (Knezevic et al., 2003 and Bhagirath et al. 2014). Plant density did not effect on seed yield or protein and oil contents, however, at low densities there was an increase in the No. of pods plant ${ }^{-1}$ (Andres et al., 2018).

Weeds pose a serious problem for crop production. Weed species include a wide range of plant types ranging from the most simple to the most complex plant forms and they vary in rooting depth, heightand spreading habits. They interfere with crop plants by competing for available light, water, space, nutrient requirements and air. Generally, an increase in $1 \mathrm{~kg}$ of weed growth corresponds to $1 \mathrm{~kg}$ reduction of crop growth as weeds remove plant nutrients more efficiently than crop plants (Jadhav, 2007). Weeds may increase the cost of production, inhibit crop growth and reduce the quality and marketability of products. Weed infestation decreases soybean yield from 50- 60\% (Jadhav, 2007) and removes $21.4 \mathrm{~kg} \mathrm{~N}$ and $3.4 \mathrm{~kg} \mathrm{P}^{-1}$ (Pandya et al., 2005). Ariunaa et al. (2016) found that Soybean can be infested by many weed species including grassy weeds and broad leaved weeds. Lamptey et al. (2015) re- 
ported that the mean predominant weed floras at the experimental field were broad leaved weeds $(58.62 \%)$, sedges $(26.93 \%)$ and grasses (14.44\%). Weed control agriculture practices include inter alia crop manipulation, rotation crop speciesand hand hoeing. However, the control of weeds using herbicides is considered to be a favorable method as it cuts the costs, time and labor. Many authors (Balyan and Malik 2003; Sylvestre et al. 2013; Singh et al. 2016 and Akter et al. 2016) demonstrated that the judicious use of pre-emergence and post-emergence herbicides for controlling grasses and broad leaved weeds increases crop yield, improves crop quality and reduces production cost.

The objective of study is to evaluate the impact of plant density and the integrated weed management using certain herbicides on Soybean yield and its associated weeds under the environmental conditions of Minia Governorate, Egypt.

\section{Materials and Methods}

\section{Experimental Farm:}

The field experiments were conducted at the experimental farm, Faculty of Agriculture, University of Minia, Egypt, during two successive summer seasons of 2015 and 2016. The soil was salty clay loam (organic

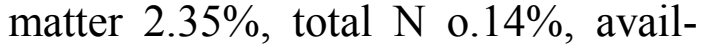
able $\mathrm{P} 18 \mathrm{ppm}$ and $\mathrm{pH}$ 7.8). The preceding winter crop was wheat in both seasons. This investigation was carried out in split-block design with three replications. The vertical plots were occupied with weed control treatments, while, the strips plots were assigned for plant spacing treatments. The plot area was $21 \mathrm{~m}^{2}$ $(4.2 \mathrm{~m}$ width $\times 5.0 \mathrm{~m}$ length). Plot width allowed for 7 and 6 ridges of soybean when planted in 60 and 70 $\mathrm{cm}$ widths, respectively.

\section{Agricultural practices}

Soybean was planted in constant spaced hills (4 and $5 \mathrm{~cm}$ apart) on one side of the ridge, at nearly 175.000 and 140.000 plants fed ${ }^{-1}$ for ridge 60 $\mathrm{cm}$ width and 150.000 and 120.000 plants $\mathrm{fed}^{-1}$ for ridge $70 \mathrm{~cm}$ width, respectively. Soybean used in the experiment was Giza 111, plots were sown by hand in the $14^{\text {th }}$ April in both seasons [soybean seeds were inoculated with bacteria (Bradyrhizobium japonicum) strain just before planting]. All recommended agronomic practices were adopted throughout the two seasons.

Weed control treatment (W): Ten weed control treatments were applied in the experiments as indicated in Table 1.

Table 1.Weed control practices applied in the experiments.

\begin{tabular}{|c|c|}
\hline No. & Treatments and dose of application \\
\hline $\mathbf{W}_{1}$ & Gesagard (FW 50\%) at rate $1.0 \mathrm{~L} \mathrm{fed}^{-1}$ \\
\hline $\mathbf{W}_{2}$ & Fusilade super (EC12.5\%) $1.0 \mathrm{~L} \mathrm{fed}^{-1}$ \\
\hline $\mathbf{W}_{3}$ & Gesagard (FW 50\%) + Fusilade super (EC12.5\%) \\
\hline $\mathbf{W}_{4}$ & Stomp (EC50\%) $1.7 \mathrm{~L} \mathrm{fed}^{-1}$ \\
\hline $\mathbf{W}_{5}$ & Stomp (EC 50\%) + Select-super (EC 12.5\%) \\
\hline $\mathbf{W}_{6}$ & Select-super $\left(12.5 \%\right.$ EC) at rate $1.0 \mathrm{~L} \mathrm{fed}^{-1}+$ hand hoeing at $60 \mathrm{DAP}$ \\
\hline $\mathbf{W}_{7}$ & Stomp (EC 50\%) + hand hoeing at 30 DAP \\
\hline $\mathbf{W}_{8}$ & Hand hoeing twice at 18 and 30 DAP \\
\hline $\mathbf{W}_{9}$ & Weed free obtained by continuous hand weeding \\
\hline $\mathbf{W}_{10}$ & Control Unweeded :Allowing weeds to grow with soybean plants \\
\hline
\end{tabular}




\section{Herbicides used}

Table (2) includes the trade name, common and chemical name, chemical structure and time of appli- cation of herbicides used in the experiments. Herbicides were sprayed by CP3 knapsack sprayer with a water volume of $200 \mathrm{~L} \mathrm{fed}^{-1}$.

Table 2. Trade name, common name, chemical structure and time of application of herbicides.

\begin{tabular}{|c|c|c|c|}
\hline $\begin{array}{l}\text { Trade } \\
\text { name }\end{array}$ & $\begin{array}{c}\text { Common name and chemical } \\
\text { name }\end{array}$ & Chemical structure & $\begin{array}{c}\text { Time of } \\
\text { application }\end{array}$ \\
\hline $\begin{array}{l}\text { Gesagard } \\
(50 \% \text { FW) } \\
1.0 \text { L fed }^{-1}\end{array}$ & $\begin{array}{l}\text { Prometryn:2,4- } \\
\text { bis(isopropylamino)-6- } \\
\text { (methylthio)-s-triazine }\end{array}$ & $\mathrm{H}_{3} \mathrm{C} \underset{\mathrm{H}}{\mathrm{C}}$ & $\begin{array}{c}\text { Pre- } \\
\text { emergence } \\
\text { Soil surface } \\
\text { application } \\
\text { directly (after } \\
\text { planting and } \\
\text { before irriga- } \\
\text { tion) }\end{array}$ \\
\hline $\begin{array}{c}\text { Fusilade } \\
\text { super } \\
(12.5 \% \text { EC) } \\
1 \mathrm{~L} \mathrm{fed}^{-1}\end{array}$ & $\begin{array}{c}\text { fluazifop-P-butyl: } \\
\text { R-2-[4-[[5-(trifluoromethyl)-2- } \\
\text { pyridinyl]oxy]phenoxy]propanate }\end{array}$ & $\begin{array}{l}\text { fluazifop-P } \\
(R)-2-[4-[[5-(\text { trifluoromethyl)-2-pyridinyl] }] \text { oxy]]phenoxy] propanoic acid }\end{array}$ & $\begin{array}{l}\text { Post- } \\
\text { emergence } \\
\text { Applied at } 30 \\
\text { days after } \\
\text { planting } \\
\text { (DAP) } \\
\end{array}$ \\
\hline $\begin{array}{l}\text { Stomp } \\
(50 \% \text { EC) } \\
1.7 \mathrm{~L} \mathrm{fed}^{-1}\end{array}$ & $\begin{array}{l}\text { pendimethalin: }[\mathrm{N}-(1- \\
\text { ethylpropyl)-3,4 dimethyl-2,6- } \\
\text { dinitrobenzen amine] }\end{array}$ & $\begin{array}{l}\text { pendimethalin } \\
N \text {-(1-ethylpropyl)-3,4-dimethyl-2,6-dinitrobenzene amine }\end{array}$ & $\begin{array}{c}\text { Pre- } \\
\text { emergence } \\
\text { soil surface } \\
\text { application } \\
\text { directly (after } \\
\text { planting and } \\
\text { before irriga- } \\
\text { tion) }\end{array}$ \\
\hline $\begin{array}{c}\text { Select- } \\
\text { super } \\
(12.5 \% \text { EC) } \\
1 \mathrm{~L} \mathrm{fed}^{-1}\end{array}$ & $\begin{array}{l}\text { clethodim:(E)-2[1-[[(3-chloro-2- } \\
\text { propenyl)oxy]imino]propyl]-5- } \\
\text { [2-(ethylthio) propyl]-3-hydroxy- } \\
\text { 2-cyclohexen-1-one }\end{array}$ & $\begin{array}{l}\text { clethodim } \\
\text { (E,E)-(+)-2-[1-[[(3-chloro-2-propenyl)oxy]imino]propyl] }\end{array}$ & $\begin{array}{l}\text { Post- } \\
\text { emergence } \\
\text { applied at } 30 \\
\text { DAP }\end{array}$ \\
\hline
\end{tabular}

Data collection and measurements:

The following data were recorded during the growing seasons.

\section{1- Weed characteristics:}

Weeds survey was conducted randomly using one square meter from each plot after 60 days from planting. Weeds species accounted as plant $\mathrm{m}^{-2}$ and hand pulled then identified and classified into three categories (narrow, broad leaved and total weeds) to estimate the following data. - Weed density (No. of weeds $\mathrm{m}^{-2}$ ).

- Dry weight of total weeds $\left(\mathrm{g} \mathrm{m}^{-2}\right)$ : all weed species $\mathrm{m}^{-2}$ were air dried for 3 days then oven dried at $70^{\circ} \mathrm{C}$ for 24 hours then weighted to estimate dry weight of total weeds.
- Weed control efficiency (\%): weed control efficiency (WCE) was calculated according to Sawant and $\operatorname{Jadav}(1985)$ as follows:

WCE $(\%)=\frac{\text { Dry weight of weeds in } \mathrm{m}^{2} \text { unweed control }=\text { Dry weight of weeds in } \mathrm{m}^{2} \text { treated }}{\text { Dry weight of } w_{\text {eed }} \mathrm{in}^{2} \text { wweed control }} \times 100$

- Weed index (WI): was calculated by using the following formula according to Gill and Vijaykumar, 1969.

$$
W I(\%)=\frac{X-Y}{X} \times 100
$$

Where:

$\mathrm{X}=$ Seed yield from maximum yield treatment.

$\mathrm{Y}=$ Seed yield from treatment for which weed index is to be calculated. 


\section{2- Soybean yield and its compo- nents:}

Five plants from each plot were selected randomly and harvested separately. The following assessments on yield components were recorded: Plant height $(\mathrm{cm})$, weight of seeds plant $^{-1}(\mathrm{~g}), 100$-seeds weight $(\mathrm{g})$, number of pods plant $^{-1}$, number of seeds pod ${ }^{-1}$ and seed yield plant ${ }^{-1}(\mathrm{~g}$ plant $\left.^{-1}\right)$. Seed and straw yield from each plot were estimated by harvesting, tying in bundles and sun dried. The bundles were weighted for biological yield. The weight of seeds obtained from each plot after threshing was converted into $\mathrm{kg} \mathrm{fed}^{-1}$.Straw yield for each plot was calculated by subtracting the seed yield from the biological yield of the respective plot.

\section{3- Seed chemical composition:}

- Oil and protein content of soybean seeds from all experimental plots were determined according to (AOAC, 1990).

- Oil and protein yield of seeds $\left(\mathrm{kg} \mathrm{fed}^{-1}\right)$ : were calculated by the following formulas:
Seed oil yield $\left(\mathrm{kg} \mathrm{fed}^{-1}\right)=\frac{(\text { Seed yield } \mathrm{x} \text { seed oil \%) }}{100}$

Seed protein yield $\left(\mathrm{kg} \mathrm{fed}^{-1}\right)=\frac{(\text { Seed yield } \mathrm{x} \text { seed protein } \%)}{100}$

\section{4- Economic evaluation of soybean production:}

The economics of all treatments were calculated by considering the prevailing prices of inputs and produce (Table 3). The various formulas used were according to Heady and Dillon (1961) as follow:

1. Total Cost of cultivation (L.E) = The cost of cultivation was calculated by considering the prevailing market price of inputs, wages and the actual cost involved in various aspects during the investigation.

2. Gross income (L.E) = price of soybean $\times$ seed yield $\left(\right.$ ton fed $\left.^{-1}\right)$

3. Net income (L.E) $=$ Gross income - Total cost.

4. Benefit Cost ratio $(\mathrm{B} / \mathrm{C})=$ Gross income / Total cost. 
Table 3. Parameters used to calculate the cost-benefit for the various inputs.

\begin{tabular}{|c|c|}
\hline Parameters & Actual values \\
\hline \multicolumn{2}{|c|}{ Price of herbicides $L$ fed $^{-1}$} \\
\hline Constant cost without cost of treatment under study & 2281 L.E fed $^{-1}$ \\
\hline Price of Gesagard $(50 \% \mathrm{FW})$ & 232 L.E \\
\hline Price of Fusilade super $(12.5 \% \mathrm{EC})$ & 265 L.E \\
\hline Price of Stomp $(50 \% \mathrm{EC})$ & 230 L.E \\
\hline Price of Select-super $(12.5 \% \mathrm{EC})$ & $360 \mathrm{~L} . \mathrm{E}$ \\
\hline Lobar wage (day), 5 farmers fed ${ }^{-1}$ & $5 \times 50=250$ L.E time ${ }^{-1}$ \\
\hline Price of grain $\left(\right.$ ton fed $\left.^{-1}\right)$ & 4336 L.E ton ${ }^{-1}$ \\
\hline Price of straw (Heap of hay) Heml $=250 \mathrm{~kg}$ & 43 L.E haml $^{-1}$ \\
\hline
\end{tabular}

\section{5- Statistical analysis:}

According to strip plot design, the data were statistically analyzed using MSTAT-C computer package program. Mean differences between treatments were evaluated by Least Significant Difference (LSD) test at $5 \%$ as suggested by Gomez and Gomez (1984).

\section{Results and Discussion 1- Weed Survey:}

Table (4) demonstrates the english and scientific names and families of dominant weed species presented in field experiments in both growing seasons at Minia region.

Table 4. Weed species found in the experimental plots of soybean.

\begin{tabular}{|c|c|c|c|c|}
\hline No & English name & Scientific name & Family & Types \\
\hline 1 & Jungle rice & Echinochloacolonum L. & Poaceae & Annual \\
\hline 2 & Green bristle grass & Setariavirids & Poaceae & narrow-leaved \\
\hline 3 & Nett leaf & Chenopodium albam L. & Chenopodiaceae & \multirow{6}{*}{$\begin{array}{c}\text { Annual } \\
\text { broad-leaved }\end{array}$} \\
\hline 4 & Common purslane & Portulaceoleraceae L. & Portulaceae & \\
\hline 5 & Cocklebur & Xanthium strumarium L. & Compositae & \\
\hline 6 & Black night shade & Solanumnigram L & Solanaceae & \\
\hline 7 & Pig weed & Amaranthusascendens L. & Amaranthaceae & \\
\hline 8 & Nut-grass & Corchorusolitorius L. & Cyperaceae & \\
\hline 9 & Bermuda grass & Cynodondactylon L. & Poeceae & \multirow{2}{*}{ Perennial narrow-leaved } \\
\hline 10 & Purplenutsedge & Cyperusrotundus L & Poeceae & \\
\hline 11 & Field bindweed & Convolvulus arvensis L. & Convolvulaceae & Perennial broad-leaved \\
\hline
\end{tabular}

\section{2- Effect of plant spacing and weed control treatments on weeds:}

Table (5) shows the effect of soybean plant spacing and weed control treatments on total dry weight of weeds at 60 DAP in 2015 and 2016 seasons. Plant spacing had a significant effect on weed density and total weeds at 60 DAP in 2015 and 2016 seasons. Narrow plant spacing $60 \times 4 \mathrm{~cm}\left(\mathrm{P}_{4}\right)$ reduced weed density and dry weight of total weeds by
27.50 and $26.68 \%$ in 2015 season and 26.38 and $22.91 \%$ in 2016 season compared to plant spacing $70 \times 5 \mathrm{~cm}$ $\left(\mathrm{P}_{1}\right)$, respectively. These results might be due to increase soybean plants/ unit increasing the ability of soybean plants to benefit from light, waterand nutrients, which prevents seedling growth of weeds. Similar results were recorded by EL-Gizawy et al. (2012) and Soliman et al. (2015). It is observed from data in table 5 that weed 
parameters including weed density and dry weight of total narrow and broad leaved weeds at 60 DAP were highly significantly decreased by using weed control treatments compared with the unweeded control in both seasons. The best treatment was $\mathrm{W}_{10}$ (weed free) in which all types of weeds were removed. Among other treatments Stomp EC50\% + one hand hoeing $\left(\mathrm{W}_{7}\right)$ followed by Stomp EC50\% + Select super EC $12.5 \%$ $\left(\mathrm{W}_{5}\right)$ was the most effective treatment, while $\mathrm{W}_{4}$ and $\mathrm{W}_{1}$ were the least effective ones. Similar results were reported by Chandraker and Paikra (2015), Soliman et al. (2015), Manjunath and Hosmath (2016), Paudel et al. (2017). The effect of plant spacing was significant in WCE in the second season only, while insignificant on weed index $\%$ in both seasons. $\mathrm{P}_{1}$ gave the highest WCE value (70.7 and $71.3 \%$ ) in both seasons, respectively. All weed control treatments effectively increased the WCE, whereas weed index was decreased as compared to unweeded check. Again, among all other weed control practices, weed free treatment was superior in reducing the growth parameters of weeds compared to all other treatments, which is reflected in WCE $(100 \%)$ and in weed Index $(0.0)$ at 60 DAP. It is followed by the treatment with Stomp EC 50\% + hand Hoeing $\left(\mathrm{W}_{7}\right)$ and Stomp EC50 $\%+$ Select super EC $12.5 \%\left(\mathrm{~W}_{5}\right) \cdot \mathrm{W}_{7}$ gave WCE 78.26 and $79.77 \%$ and weed index 2.74 and $2.44 \%$ in 2015 and 2016 seasons, respectively.

Table 5. Effect of soybean plant spacing and weed control treatments on weed growth parameters at 60 DAP in 2015 and 2016 seasons.

\begin{tabular}{|c|c|c|c|c|c|c|c|c|}
\hline \multirow[t]{2}{*}{ Treatments } & \multicolumn{2}{|c|}{$\begin{array}{l}\text { weed density } \\
\left(\text { no. } \mathrm{m}^{-2}\right)\end{array}$} & \multicolumn{2}{|c|}{$\begin{array}{c}\text { Total dry } \\
\text { weight of } \\
\text { weeds }\left(\mathrm{g} \mathrm{m}^{-2}\right)\end{array}$} & \multicolumn{2}{|c|}{$\begin{array}{l}\text { Weed control } \\
\text { efficiency }(\%)\end{array}$} & \multicolumn{2}{|c|}{$\begin{array}{l}\text { Weed index } \\
(\%)\end{array}$} \\
\hline & 2015 & 1016 & 2015 & 2016 & 2015 & 2016 & 2015 & 2016 \\
\hline \multicolumn{9}{|l|}{ P- Plant Spacing ( cm ): } \\
\hline$P_{1}: 60 \mathrm{~cm} \times 4 \mathrm{~cm} 1$ side $=175.000$ plant fed $^{-1}$ & 70.43 & 68.12 & 30.52 & 28.34 & 70.70 & 71.32 & 11.03 & 10.94 \\
\hline$P_{2}: 60 \mathrm{~cm} \times 5 \mathrm{~cm} 1$ side $=140.000$ plant fed $^{-1}$ & 86.07 & 83.44 & 37.11 & 31.08 & 70.32 & 71.81 & 11.42 & 11.65 \\
\hline$P_{3}: 70 \mathrm{~cm} \times 4 \mathrm{~cm} 1$ side $=150.000$ plant fed $^{-1}$ & 77.72 & 73.92 & 33.36 & 31.24 & 70.02 & 72.47 & 11.09 & 11.01 \\
\hline$P_{4}: 70 \mathrm{~cm} \times 5 \mathrm{~cm} 1$ side $=120.000$ plant fed $^{-1}$ & 97.14 & 92.53 & 41.59 & 36.76 & 70.53 & 69.63 & 12.40 & 11.74 \\
\hline LSD $_{(0.05)}$ & 0.94 & 1.19 & 0.19 & 0.57 & NS & 1.11 & NS & NS \\
\hline \multicolumn{9}{|l|}{ W- Weed control treatments $\left(\mathrm{L} \mathrm{fed}^{-1}\right)$ : } \\
\hline$W_{1}$ : Gesagard $(50 \% \mathrm{FW})$ at the rate $1.0 \mathrm{~L}$ & 71.06 & 67.75 & 30.74 & 27.07 & 67.74 & 68.77 & 11.02 & 10.77 \\
\hline$W_{2}:$ Fusilade super $(12.5 \%$ EC) at the rate $1.0 \mathrm{~L}$ & 85.42 & 81.98 & 36.85 & 34.28 & 61.33 & 60.46 & 13.30 & 13.15 \\
\hline $\mathrm{W}_{3}$ : Gesagard + Fusilade super & 56.09 & 53.70 & 24.80 & 21.25 & 73.97 & 75.49 & 5.14 & 4.93 \\
\hline $\mathrm{W}_{4}:$ Stomp $(50 \% \mathrm{EC})$ at the rate $1.7 \mathrm{~L}$ & 68.52 & 65.65 & 29.14 & 27.45 & 69.49 & 68.34 & 8.17 & 7.71 \\
\hline $\mathrm{W}_{5}:$ Stomp + Fusilade & 52.47 & 49.51 & 23.60 & 20.32 & 75.23 & 76.56 & 4.51 & 3.40 \\
\hline $\mathrm{W}_{6}$ : Select-Super $(12.5 \% \mathrm{EC})$ at the rate $1.0 \mathrm{~L}$ & 84.00 & 81.18 & 36.45 & 33.42 & 61.75 & 61.45 & 12.74 & 12.36 \\
\hline$W_{7}:$ Stomp +1 hand hoeing & 47.60 & 44.41 & 20.72 & 17.54 & 78.26 & 79.77 & 2.74 & 2.44 \\
\hline$W_{8}$ : Hand hoeing (2) & 55.89 & 52.83 & 24.18 & 21.32 & 74.62 & 75.41 & 4.57 & 4.42 \\
\hline$W_{9}$ : Unweeded check & 224.54 & 218.54 & 95.29 & 86.69 & 0.0 & 0.0 & 43.18 & 42.69 \\
\hline $\mathrm{W}_{10}$ : Weed free & 0.0 & 0.0 & 0.0 & 0.0 & 100 & 100 & 0.0 & 0.0 \\
\hline $\operatorname{LSD}_{(0.05)}$ & 0.58 & 0.91 & 0.66 & 0.57 & 0.69 & 0.62 & 2.79 & 2.04 \\
\hline F-test & $*$ & $*$ & * & $*$ & $*$ & $*$ & NS & NS \\
\hline
\end{tabular}

The lowest WCE and weed Index were obtained after treatment with Fusilade super EC 12.5\% giving $(61.3$ and $60.5 \%)$ and (13.3 and $13.2 \%$ ) in 2015 and 2016 seasons, respectively. Nandini Devi et al. (2016) reported that weed index was high in the control treatment $(42.10 \%)$ followed by the preemergence application of 
pendimethalin $(19.09 \%)$. Our results are in line with those of Sylvestre et al. (2013), Chandraker and Paikra (2015), Thakare et al. (2015), Akter et al. (2016), Aradhana Bal et al.(2016), Manjunath and Hosmath (2016), Singh et al. (2016) and Paudel et al. (2017).

\section{3- Effect of plant spacing and weed control treatments on soybean yield and its components:}

a- Plant height, weight of seeds plant $^{-1}$ and 100 -seeds weight:

Results in Table 6 show that the plant height increased significantly from 88.03 to $95.74 \mathrm{~cm}$ and from 89.20 to $96.81 \mathrm{~cm}$ in 2015 and 2016 seasons when plant density was increased from 120.000 to 175.000 plant fed $^{-1}$ respectively. This increase in plant height with closer spacing might have resulted due to competition among plants for sunlight. Similar results were observed by other researchers Akond et al. (2013), Chaunhan and Opena (2013), El-Far et al. (2016), Asmaa et al. (2017) and Gulluoglu et al. (2016 and 2017).

On the contrary, the highest values of weight of seeds plant ${ }^{-1}$ (20.37 and $20.59 \mathrm{~g}$ ) and 100-seeds weight (19.05 and $19.20 \mathrm{~g}$ ) were obtained from $\mathrm{P}_{4}$ in 2015 and 2016 seasons, respectively. This is attributed to the increase in distance between ridges and hill which reduced the competition among plants and consequently gave the chance for them to grow properly, then an increase in the weight of seeds plant ${ }^{-1}$ and 100 -seeds weight could be expected. These results are supported by the results of Saitoh (2011), Akond et al. (2013) and Gulluoglu et al. (2016 and 2017).
As shown in Table 6, the different weed control treatments remarkably affect plant height, weight of seeds plant ${ }^{-1}$ and 100-seeds weight .The three parameters were significantly improved by weed control treatments compared to the unweeded check. Maximum plant height (101.39 and $102.52 \mathrm{~cm})$, weight of seeds plant ${ }^{-1}$ (24.78 and $25.22 \mathrm{~g})$ and 100 -seeds weight ( 21.26 and $21.44 \mathrm{~g}$ ) were recorded by weed free treatment $\left(\mathrm{W}_{10}\right)$ in 2015 and 2016 seasons, respectively. It is followed in a descending order by $\mathrm{W}_{7}, \mathrm{~W}_{5}, \mathrm{~W}_{8}, \mathrm{~W}_{3}, \mathrm{~W}_{4}, \mathrm{~W}_{1}, \mathrm{~W}_{6}$ and $\mathrm{W}_{2}$. The unweeded control gave the least values. Sylvesre et al.(2013); Hassan(2015); Thakare et al.(2015); Nandini Devi et al.(2016) and Rajkumari et al.(2017a) found similar results.

b- Number of pods plant ${ }^{-1}$, number of seeds pod $^{-1}$ and weight of pods plant $^{-1}$ :

Number of pods plant ${ }^{-1}$, number of seeds pod $^{-1}$ and weight of pods plant $^{-1}$ were estimated for each treatment and included in Table 6. The distance between plants had a significant effect on pod characters. No. of pods plant ${ }^{-1}$ increased from 40.24 to 49.18 and from 40.94 to 50.49 pod plant $^{-1}$, No. of seeds pod ${ }^{1}$ from 2.0 to 2.53 and from 2.11 to 2.70 seed and weight of pods plant ${ }^{-1}$ from 22.86 to $26.91 \mathrm{~g}$ and from 23.19 to $28.26 \mathrm{~g}$, as plant spacing increased from $60 \times 4 \mathrm{~cm}\left(\mathrm{P}_{1}\right)$ to $70 \times 5 \mathrm{~cm}\left(\mathrm{P}_{4}\right)$ in 2015 and 2016 seasons, respectively. The increase in same characters due to increase space between ridges and hills may be attributed to the increased availability of nutrients and sunlight for soybean plants than nar- 
rowing ridges and plant spacing. These results are in agreement with findings of Seadh and Abido (2013), Hassan (2015), Asmaa et al. (2017), Gulluoglu et al. (2016 and 2017), Andres et al. (2018) and Matsuo et al. (2018).

Concerning the effect of weed control treatments on these characters (Table 6), it has been found that the weed free treatment (W10) was superior in No. of pod plant ${ }^{-1}$ indicating 62.43 and 62.63 , No. of seeds pod-1 2.90 and 3.00 and weight of pods plant $^{-1} 34.5$ and $34.7 \mathrm{~g}$ in 2015 and 2016 seasons, respectively, which is statistically at par with using Stomp EC50\% + one hand hoeing (W7) (No. of pod plant ${ }^{-1}$ were 56.49 and 57.35, No. of seeds pod-1 2.82 and 2.91 and weight of pods plant ${ }^{-1} 33.45$ and 33.63 $\mathrm{g}$ in 2015 and 2016 seasons, respectively).

Both treatments were followed by Stomp EC50\% + Select-super $\mathrm{EC} 12.5 \%$ (W5) and hand hoeing twice (W8) which was superior to weed control by using Fusilade super EC $12.5 \%$ (W2) that was the least effective one among treatments, followed by the unweedwed check. These results are similar to those obtained by Seadh and Abido (2013), Akter et al. (2016) and Hosseini et al. (2016).

\section{c- Seed, straw and biological yield.}

Data in Table (6) indicate that the yields of soybean increased steadily by increasing plant density from $120.000\left(\mathrm{P}_{4}\right)$ to $175.000\left(\mathrm{P}_{1}\right)$ plant $\mathrm{fed}^{-1}$. Seed yield, straw yield and biological yield have been gradually raised from 1.22, 2.33 and $3.56(\mathrm{P} 4)$ to $1.31,2.46$ and $3.80\left(\mathrm{P}_{1}\right)$ ton $\mathrm{fed}^{-1}$ in 2015 season and from $1.25,2.36$ and $3.61\left(\mathrm{P}_{4}\right)$ to $1.32,2.48$ and 3.80 (P1) ton $\mathrm{fed}^{-1}$ in 2016 season, respectively. The same results were reported by Seadh and Abido (2013), Hassan (2015), El-Far et al. (2016) Asmaa et al. (2017), Gulluoglu et al. (2017) and Matsuo et al. (2018).

Regarding the effect of weed control treatments on the seeds yield, straw yield and biological yield (Table 6), data reported that the three parameters have been increased by all weed control treatments. The best results were obtained by W10 followed by W7, W5, W8, W3, W4, W1, W6 and $\mathrm{W} 2$ treatments in both seasons.

This increase is reflected on soybean yields compared to the unweeded control (Table 7). The highest increasing $\%$ of seed yield $(106 \%)$, straw yield $(50 \%)$ and biological yield (66\%) resulted from W10 followed by W7, W5, W8, W3, W4, W1, W6 and W2 treatments. These results are in line with those obtained by Chandraker and Paikra (2015), Soliman et al. (2015), Manjunath and Hosmath (2016), Paudel et al. (2017) and Kulal et al. (2017).

\section{4- Effect of plant spacing and weed control treatments on quality stud- ies: \\ Protein content $\%$ and protein yield:}

Protein $\%$ and protein yield of soybean seeds were significantly influenced due to different plant spacing (Table 8). The highest protein content $\%$ was obtained by using plant spacing of $70 \times 5 \mathrm{~cm}\left(\mathrm{P}_{4}\right)$ followed by $60 \times 5 \mathrm{~cm}\left(\mathrm{P}_{2}\right), 70 \times 4 \mathrm{~cm}\left(\mathrm{P}_{3}\right)$ and $60 \times 4 \mathrm{~cm}\left(\mathrm{P}_{1}\right)$ in decreasing order. $\mathrm{P}_{4}$ gave a superiorityof protein yield when compared with other spacing in the two seasons. These re- 
sults could be attributed to that in wider spacing the plants were able to from more metabolites to synthesize more protein in the seeds and the activity of protein synthesis was higher than at closer spacing. Similar results were obtained by Galal (2004), Ibrahim and Kandil (2007), Seadh and Abido (2013) and Andres et al. (2018).

The data regarding the protein percent and protein yield in soybean seed as influenced by weed control treatments are presented in (Table 8). The results indicated significant highest protein content in treatment $\mathrm{W}_{10}$ (38.61 and $\left.38.69 \%\right)$, followed by treatment $\mathrm{W}_{7}$ (38.33 and $38.51 \%$ ), $\mathrm{W}_{5}(38.04$ and $38.24 \%)$ and $\mathrm{W}_{8}$ (37.86 and $38.03 \%$ ) in 2015 and 2016 seasons, respectively. Significantly lowest protein content was estimated in unweeded treatment (34.61 and $34.68 \%$ ) in both seasons. These results could be attributed to the better $\mathrm{N}$ utilization by soybean plants under these treatments that favored by effective elimination of weeds. Weed infestation for whole growing season in unweeded plots was instrumental in reduced protein content in same plots. This result supports the results of Shaikh et al. (2010), Peer et al. (2013), Singh (2015), Soliman et al. (2015) and Rajkumari et al. (2017a). The same data showed that all treatments increased protein yield $\mathrm{kg} \mathrm{fed}^{-1}$ when compared with the unweeded treatment (Table 8). This may be probably due to the better weed control practices resulting improvement in seed yield. However, Singh et al. (2014) did not find significant variation in protein content of the seed soybean due to the weed control practices. 


\section{Oil content \% and oil yield:}

Data presented in (Table 8) show that increasing plant spacing $60 \times 4 \mathrm{~cm} \quad\left(\mathrm{P}_{1}\right)$ to $70 \times 5 \mathrm{~cm} \quad\left(\mathrm{P}_{4}\right)$ significantly decreased the seed oil $\%$ in soybean. The oil \% values varied between 20.76 to $20.11 \%$ in 2015 and 20.89 to $20.37 \%$ in 2016 , as well as oil yield fed $\mathrm{fed}^{-1} 335.54$ to $308.61 \mathrm{~kg}$ fed $^{-1}$ in 2015 and 340.72 to $316.78 \mathrm{~kg}$ $\mathrm{fed}^{-1}$ in 2016 . The highest value of the seed oil \% (20.76 and $20.89 \%$ ) was obtained when the plant spacing of $60 \times 4 \mathrm{~cm}\left(\mathrm{P}_{1}\right)$ was used followed by plant spacing $70 \times 5 \mathrm{~cm}\left(\mathrm{P}_{4}\right)$. The highest values of oil yield fed $^{-1}$ at the closer spacing may be due to the highest seed yield fed $^{-1}$ with the same spacing. These results are in harmony with those recorded by Galal (2004), Ibrahim and Kindil (2007), Gulluoglu et al. (2016) and Andres et al.(2018). On the other hand, Gulluoglu et al. (2017) found that the oil content of soybean was insignificant in plant spacing in two seasons.

All the weed control practices gave significantly higher oil content and oil yield compared to the unweeded treatment. The maximum oil content was recorded to $\mathrm{W}_{10}(22.51$ and $22.71 \%)$ and $\mathrm{W}_{7}(22.23$ and $22.43 \%$ ) in both seasons. It was at par with $\mathrm{W}_{5}(22.01$ and $22.20 \%)$ and $\mathrm{W}_{8}$ (20.95 and $21.17 \%$ ) followed by $\mathrm{W}_{3}$ (20.48 and 20.66\%) in 2015 and 2016 seasons, respectively. Meanwhile, the lowest oil content was obtained from the unweeded treatment. Oil yield losses from weed infestation reached 211.10 and $212.35 \mathrm{~kg}$ oil fed $\mathrm{fe}^{-1}(48.50$ and $48.30 \%$ ) as compared to the oil estimated from usingweed free for whole season $\mathrm{W}_{10}$ (356.89 and 364.27 $\left.\mathrm{kg} \mathrm{fed}{ }^{-1}\right)$ in $1^{\text {st }}$ and $2^{\text {nd }}$ seasons, respectively. Therefore, elimination of weeds which increased oil yield may be due to effectiveness of the used weed control treatments. Increased oil content and oil yield fed $^{-1}$ in soybean under weed control treatments has also been reported by Shaikh et al. (2010), Peer et al. (2013), Singh (2015), Soliman et al. (2015) and Rajkumari et al. (2017a).

Table 8. Effect of plant spacing and weed control treatments on protein and oil content of soybean crop in $1^{\text {st }}$ and $2^{\text {nd }}$ seasons.

\begin{tabular}{|c|c|c|c|c|c|c|c|c|}
\hline \multirow[t]{2}{*}{ Treatments } & \multicolumn{2}{|c|}{ Protein \% } & \multicolumn{2}{|c|}{$\begin{array}{l}\text { Protein yeild } \\
\quad\left(\mathrm{kg} \mathrm{fed}^{-1}\right)\end{array}$} & \multicolumn{2}{|c|}{$\begin{array}{c}\text { Oil } \\
\text { content } \%\end{array}$} & \multicolumn{2}{|c|}{$\begin{array}{l}\text { Oil yeild } \\
\left(\mathrm{kg} \mathrm{fed}^{-1}\right)\end{array}$} \\
\hline & \multicolumn{2}{|c|}{$2015 / 2016$} & \multicolumn{2}{|c|}{$2015 / 2016$} & \multicolumn{2}{|c|}{$2015 / 2016$} & \multicolumn{2}{|c|}{$2015 / 2016$} \\
\hline \multicolumn{9}{|l|}{ P- Plant Spacing ( cm ): } \\
\hline$P_{1}: 60 \mathrm{~cm} \times 4 \mathrm{~cm} 1$ side $=175.000$ plant fed $^{-1}$ & 36.91 & 37.05 & 594.51 & 603.77 & 20.76 & 20.89 & 335.54 & 340.72 \\
\hline$P_{2}: 60 \mathrm{~cm} \times 5 \mathrm{~cm} 1$ side $=140.000$ plant fed $^{-1}$ & 37.38 & 37.57 & 585.58 & 593.38 & 20.31 & 20.48 & 317.86 & 324.50 \\
\hline$P_{3}: 70 \mathrm{~cm} \times 4 \mathrm{~cm} 1$ side $=150.000$ plant ed $^{-1}$ & 37.12 & 37.34 & 589.29 & 597.51 & 20.55 & 20.75 & 326.99 & 333.15 \\
\hline$P_{4}: 70 \mathrm{~cm} \times 5 \mathrm{~cm} 1$ side $=120.000$ plant fed $^{-1}$ & 37.60 & 37.78 & 575.87 & 586.22 & 20.11 & 20.37 & 308.61 & 316.78 \\
\hline LSD $_{(0.05)}$ & 0.09 & 0.06 & 8.35 & 6.15 & 0.18 & 0.06 & 4.13 & 3.65 \\
\hline \multicolumn{9}{|l|}{ W- Weed control treatments $\left(\mathrm{L} \mathrm{fed}^{-1}\right)$ : } \\
\hline $\mathrm{W}_{1}$ : Gesagard $(50 \% \mathrm{FW})$ at the rate $1.0 \mathrm{~L}$ & 36.95 & 37.11 & 575.18 & 584.09 & 19.49 & 19.65 & 296.34 & 301.18 \\
\hline $\mathrm{W}_{2}:$ Fusilade super $(12.5 \% \mathrm{EC})$ at the rate $1.0 \mathrm{~L}$ & 36.49 & 36.69 & 554.16 & 562.43 & 19.08 & 19.27 & 297.14 & 303.32 \\
\hline $\mathrm{W}_{3}$ : Gesagard + Fusilade super & 37.49 & 37.68 & 618.52 & 629.59 & 20.48 & 20.66 & 340.12 & 346.44 \\
\hline $\mathrm{W}_{4}:$ Stomp $(50 \% \mathrm{EC})$ at the rate $1.7 \mathrm{~L}$ & 37.32 & 37.54 & 599.69 & 609.27 & 19.72 & 19.91 & 301.43 & 307.82 \\
\hline $\mathbf{W}_{5}:$ Stomp + Fusilade super & 38.04 & 38.24 & 641.87 & 653.57 & 22.01 & 22.20 & 368.14 & 374.27 \\
\hline $\mathrm{W}_{6}$ : Select-Super $(12.5 \% \mathrm{EC})$ at the rate $1.0 \mathrm{~L}$ & 36.89 & 37.09 & 569.44 & 572.39 & 19.40 & 19.63 & 311.97 & 319.50 \\
\hline $\mathrm{W}_{7}:$ Stomp +1 hand hoeing & 38.33 & 38.51 & 652.83 & 662.90 & 22.23 & 22.42 & 371.78 & 382.10 \\
\hline $\mathrm{W}_{8}$ : Hand hoeing (2) & 37.86 & 38.03 & 632.27 & 643.42 & 20.95 & 21.17 & 356.89 & 364.27 \\
\hline$W_{9}$ : Unweeded check & 34.53 & 34.68 & 343.29 & 350.27 & 18.44 & 18.61 & 183.79 & 188.31 \\
\hline$W_{10}:$ Weed free & 38.61 & 38.79 & 675.89 & 684.30 & 22.55 & 22.71 & 394.89 & 400.66 \\
\hline LSD $_{(0.05)}$ & 0.40 & 0.46 & 26.65 & 24.03 & 0.56 & 0.56 & 15.60 & 15.09 \\
\hline F-test & NS & NS & NS & NS & NS & NS & NS & NS \\
\hline
\end{tabular}




\section{5- Effect of interaction:}

Data in Table 9 presents the interaction effect between plant spacing and weed control treatments. It was a significant effect on weed density, total dry weeds and weed control efficiency (WCE) at 60 DAP in both seasons. All weed control treatments caused significant reductions in No. of weeds, compared to the unweeded check. The greatest reduction in weed density and dry weight of total weeds was produced from plant spacing $\mathrm{P}_{1}$ and weed control treatment $\mathrm{W}_{7}$ followed by $\mathrm{P}_{3}$ with $\mathrm{W}_{7}$ as compared to the low plant density $\mathrm{P}_{4}$ with $\mathrm{W}_{7}$ in both seasons. This may be due to increasing competition ability of soybean in utilization nutrients, water and sunlight due to increasing soybean plants units ${ }^{-1}$ and decreased weed plants. Weed free plots $\left(\mathrm{W}_{10}\right)$ in all plant space treatments recorded the greatest WCE followed by $\mathrm{P}_{1} \times \mathrm{W}_{7}$.

Table 9. Effect of interaction between plant spacing and weed control treatments on weed density, total dry weight of weeds and weed control efficiency at 60 DAP in 2015 and 2016 seasons.

\begin{tabular}{|c|c|c|c|c|c|c|c|}
\hline \multicolumn{2}{|r|}{ Treatments } & \multirow{2}{*}{\multicolumn{2}{|c|}{ Weed density }} & \multirow{2}{*}{\multicolumn{2}{|c|}{$\begin{array}{l}\text { Total dry weight of } \\
\text { weeds }\left(\mathrm{g} \mathrm{m}^{-1}\right)\end{array}$}} & \multirow{2}{*}{\multicolumn{2}{|c|}{$\begin{array}{l}\text { Weed control } \\
\text { efficiency } \%\end{array}$}} \\
\hline \multirow{2}{*}{$\begin{array}{c}\text { Plant spac- } \\
\text { ing }\end{array}$} & \multirow{2}{*}{ Weed control treatments } & & & & & & \\
\hline & & 2015 & 2016 & 2015 & 2016 & 2015 & 2016 \\
\hline \multirow{10}{*}{$\begin{array}{c}P_{1:} \\
60 \times 4 \mathrm{~cm} \\
175.000 \\
\text { Plant fed }^{-1}\end{array}$} & $W_{1}$ : Gesagard $(50 \% \mathrm{FW})$ at the rate $1.0 \mathrm{~L}$ & 58.27 & 56.00 & 25.53 & 23.68 & 59.10 & 59.92 \\
\hline & $\mathrm{W}_{2}:$ Fusilade super $(12.5 \% \mathrm{EC})$ at the rate $1.0 \mathrm{~L}$ & 76.78 & 73.47 & 33.60 & 31.04 & 68.92 & 69.41 \\
\hline & $\mathrm{W}_{3}$ : Gesagard + Fusilade super & 47.26 & 44.33 & 21.19 & 19.33 & 75.28 & 77.36 \\
\hline & $\mathrm{W}_{4}: \operatorname{Stomp}(50 \% \mathrm{EC})$ at the rate $1.7 \mathrm{~L}$ & 58.07 & 56.20 & 25.24 & 24.53 & 62.31 & 61.31 \\
\hline & $\mathrm{W}_{5}:$ Stomp + Fusilade super & 43.35 & 41.84 & 18.36 & 16.88 & 77.64 & 78.21 \\
\hline & $\mathrm{W}_{6}:$ Select-Super $(12.5 \% \mathrm{EC})$ at the rate $1.0 \mathrm{~L}$ & 71.64 & 69.90 & 30.96 & 29.95 & 69.27 & 68.32 \\
\hline & $\mathrm{W}_{7}:$ Stomp + 1 hand hoeing & 39.31 & 37.73 & 17.33 & 14.70 & 78.91 & 81.02 \\
\hline & $W_{8}$ : Hand hoeing (2) & 46.89 & 45.67 & 20.31 & 17.53 & 74.20 & 75.03 \\
\hline & $\mathrm{W}_{9}$ : Unweeded check & 192.33 & 187.90 & 82.15 & 77.45 & 0.0 & 0.0 \\
\hline & $\mathrm{W}_{10}:$ Weed free & $\mathbf{0 . 0}$ & 0.0 & 0.0 & $\mathbf{0 . 0}$ & 100 & 100 \\
\hline \multirow{10}{*}{$\begin{array}{c}P_{2:} \\
60 \times 5 \mathrm{~cm} \\
140.000 \\
\text { Plant fed }^{-1}\end{array}$} & $\mathrm{~W}_{1}$ : Gesagard $(50 \% \mathrm{FW})$ at the rate $1.0 \mathrm{~L}$ & 78.55 & 76.67 & 34.39 & 26.42 & 62.50 & 63.53 \\
\hline & $\mathrm{W}_{2}:$ Fusilade super $(12.5 \% \mathrm{EC})$ at the rate $1.0 \mathrm{~L}$ & 86.14 & 83.10 & 37.42 & 32.71 & 62.32 & 68.93 \\
\hline & $\mathrm{W}_{3}$ : Gesagard + Fusilade super & 58.11 & 56.93 & 25.25 & 20.12 & 74.56 & 76.56 \\
\hline & $\mathrm{W}_{4}:$ Stomp $(50 \% \mathrm{EC})$ at the rate $1.7 \mathrm{~L}$ & 70.62 & 66.87 & 29.80 & 27.14 & 62.32 & 61.54 \\
\hline & $\mathrm{W}_{5}:$ Stomp + Fusilade super & 54.86 & 52.62 & 23.30 & 19.07 & 75.84 & 77.58 \\
\hline & $\mathrm{W}_{6}$ : Select-Super $(12.5 \% \mathrm{EC})$ at the rate $1.0 \mathrm{~L}$ & 85.16 & 82.63 & 37.20 & 31.01 & 69.96 & 68.09 \\
\hline & $\mathrm{W}_{7}:$ Stomp +1 hand hoeing & 49.79 & 46.37 & 22.22 & 18.23 & 77.60 & 78.56 \\
\hline & $W_{8}$ : Hand hoeing (2) & 56.91 & 54.50 & 25.24 & 19.93 & 74.54 & 76.34 \\
\hline & $W_{9}$ : Unweeded check & 234.50 & 231.27 & 99.19 & 85.05 & 0.0 & 0.0 \\
\hline & $\mathrm{W}_{10}:$ Weed free & $\mathbf{0 . 0}$ & $\mathbf{0 . 0}$ & 0.0 & $\mathbf{0 . 0}$ & 100 & 100 \\
\hline \multirow{10}{*}{$\begin{array}{c}P_{3:} \\
70 \times 4 \mathrm{~cm} \\
150.000 \\
\text { Plant fed }^{-1}\end{array}$} & $\mathrm{~W}_{1}$ : Gesagard $(50 \% \mathrm{FW})$ at the rate $1.0 \mathrm{~L}$ & 63.21 & 60.95 & 27.04 & 25.78 & 61.13 & 63.31 \\
\hline & $\mathrm{W}_{2}:$ Fusilade super $(12.5 \% \mathrm{EC})$ at the rate $1.0 \mathrm{~L}$ & 84.64 & 81.23 & 36.35 & 33.17 & 69.69 & 71.13 \\
\hline & $\mathrm{W}_{3}$ : Gesagard + Fusilade super & 51.00 & 46.80 & 23.94 & 20.65 & 75.61 & 77.36 \\
\hline & $\mathrm{W}_{4}:$ Stomp $(50 \% \mathrm{EC})$ at the rate $1.7 \mathrm{~L}$ & 60.69 & 56.17 & 26.77 & 25.35 & 58.86 & 62.21 \\
\hline & $\mathrm{W}_{5}:$ Stomp + Fusilade super & 52.58 & 49.43 & 21.56 & 19.88 & 74.16 & 77.40 \\
\hline & $\mathrm{W}_{6}$ : Select-Super $(12.5 \% \mathrm{EC})$ at the rate $1.0 \mathrm{~L}$ & 80.62 & 77.37 & 34.34 & 32.21 & 69.40 & 70.64 \\
\hline & $\mathrm{W}_{7}:$ Stomp +1 hand hoeing & 53.39 & 50.54 & 19.03 & 16.49 & 72.89 & 76.48 \\
\hline & $\mathrm{W}_{8}$ : Hand hoeing (2) & 44.46 & 41.10 & 22.81 & 19.84 & 78.46 & 81.22 \\
\hline & $\mathrm{W}_{9}$ : Unweeded check & 208.89 & 201.73 & 88.36 & 87.80 & 0.0 & 0.0 \\
\hline & $\mathrm{W}_{10}:$ Weed free & $\mathbf{0 . 0}$ & 0.0 & 0.0 & $\mathbf{0 . 0}$ & 100 & 100 \\
\hline \multirow{10}{*}{$\begin{array}{c}P_{4:} \\
60 \times 5 \mathrm{~cm} \\
120.000 \\
\text { Plant fed }^{-1}\end{array}$} & $\mathrm{~W}_{1}$ : Gesagard $(50 \% \mathrm{FW})$ at the rate $1.0 \mathrm{~L}$ & 86.72 & 82.17 & 36.27 & 32.79 & 62.09 & 59.74 \\
\hline & $\mathrm{W}_{2}$ :Fusilade super $(12.5 \% \mathrm{EC})$ at the rate $1.0 \mathrm{~L}$ & 98.15 & 94.00 & 42.25 & 38.82 & 67.46 & 66.01 \\
\hline & $W_{3}$ : Gesagard + Fusilade super & 66.78 & 62.77 & 28.32 & 23.96 & 74.14 & 74.20 \\
\hline & $\mathrm{W}_{4}:$ Stomp $(50 \% \mathrm{EC})$ at the rate $1.7 \mathrm{~L}$ & 82.20 & 78.57 & 35.57 & 32.35 & 63.17 & 60.75 \\
\hline & $\mathbf{W}_{5}:$ Stomp + Fusilade super & 60.69 & 56.77 & 26.20 & 22.92 & 76.49 & 76.23 \\
\hline & $\mathrm{W}_{6}$ : Select-Super $(12.5 \% \mathrm{EC})$ at the rate $1.0 \mathrm{~L}$ & 94.44 & 90.97 & 41.05 & 37.86 & 68.09 & 66.45 \\
\hline & $\mathrm{W}_{7}:$ Stomp +1 hand hoeing & 56.84 & 52.43 & 24.32 & 20.75 & 78.19 & 78.49 \\
\hline & $\mathrm{W}_{8}$ : Hand hoeing (2) & 66.00 & 61.84 & 28.83 & 24.89 & 74.59 & 75.16 \\
\hline & $\mathrm{W}_{9}$ : Unweeded check & 262.45 & 253.27 & 111.47 & 96.47 & $\mathbf{0 . 0}$ & 0.0 \\
\hline & $W_{10}:$ Weed free & 0.0 & 0.0 & 0.0 & 0.0 & 100 & 100 \\
\hline \multicolumn{2}{|r|}{ L.S.D 0.05} & 1.17 & 1.81 & 1.32 & 1.13 & 1.38 & 1.24 \\
\hline
\end{tabular}


Figures $(1 \& 2)$ illustrate that the interaction between plant spacing and weed control treatments have a significant effect on weight of seeds plant-1, weight of pods plant ${ }^{-1}$, straw yield and biological yield in both seasons. The combination of the low plant density $\left(\mathrm{P}_{4}=120.000\right.$ plant fed $\left.^{-1}\right)$ and weed free treatment $\left(\mathrm{W}_{10}\right)$ recorded the highest values of weight of seeds plant ${ }^{-1}$ (26.25 and 26.61 g)and weight of pods plant ${ }^{-1}(36.67$ and $36.60 \mathrm{~g}$ ) in $1^{\text {st }}$ and $2^{\text {nd }}$ seasons, respectively.
$\mathrm{P}_{1} \times \mathrm{W}_{10}$ gave the greatest values of straw and biological yields $(2.70$ and 2.72 ton $\left.\mathrm{fed}^{-1}\right)$ and (4.19 and 4.22 ton $\mathrm{fed}^{-1}$ ), in 2015 and 2016 seasons respectively,(figures $3 \& 4$ ). The second best interaction treatment was $\mathrm{P}_{1} \times \mathrm{W}_{7}$, followed by $\mathrm{P}_{3} \times \mathrm{W}_{10}$ in both seasons, while planting 120.000 plant fed $^{-1}$ with unweeded control treatment gave the lowest straw and biological yields in two seasons. These results are coincidence with those obtained by Asmaa et al. (2017).
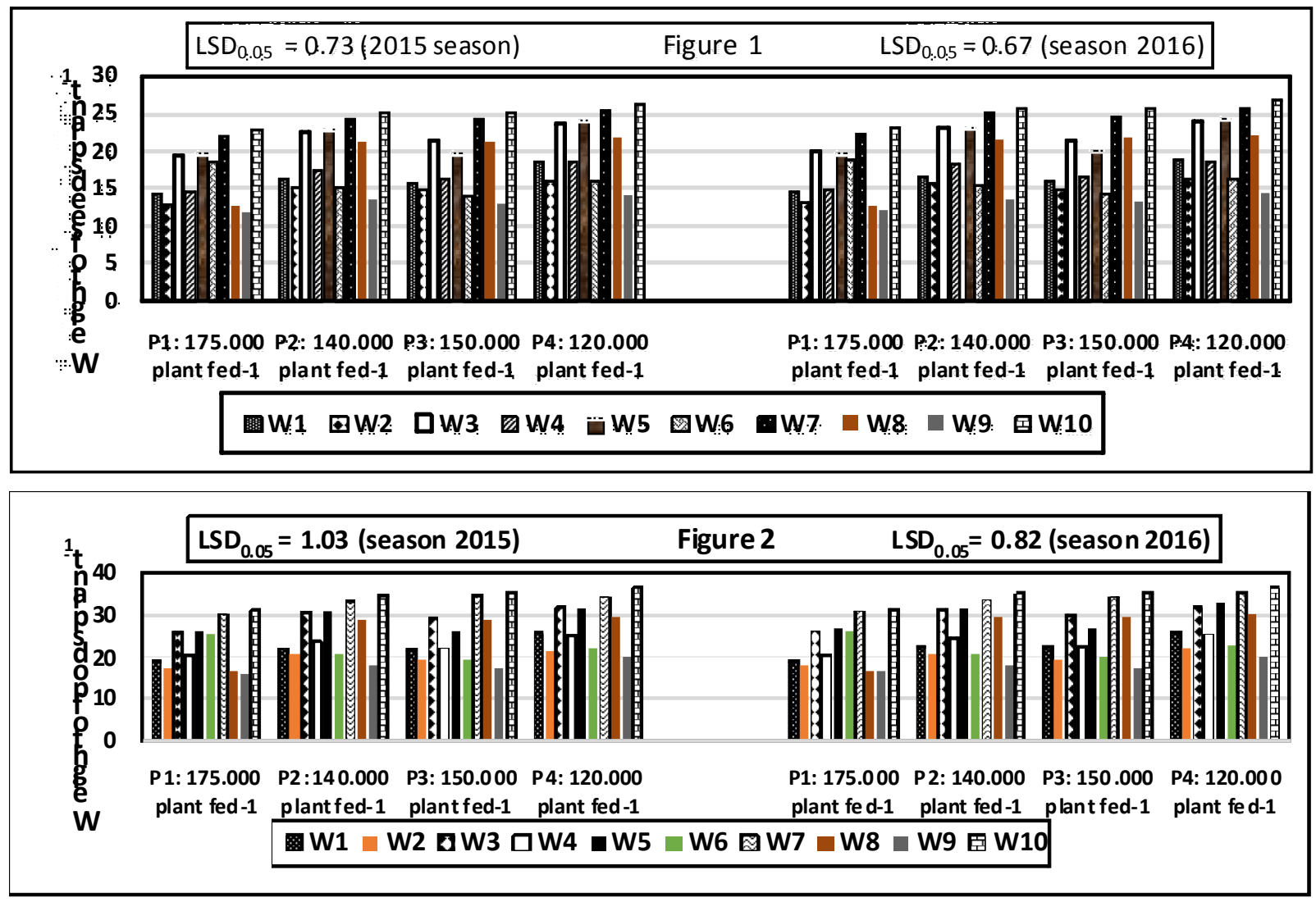

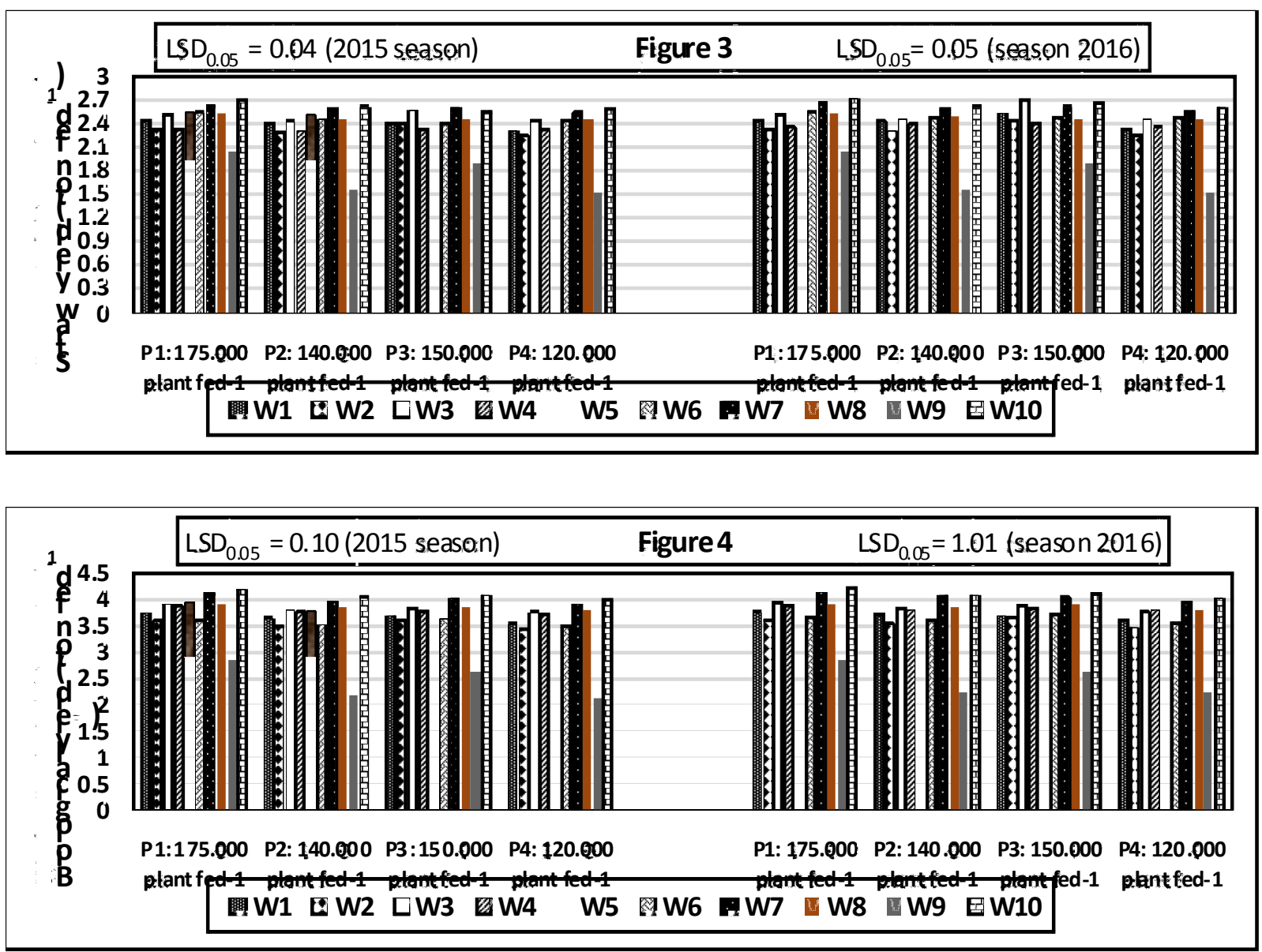

Figures (1, 2, 3 and 4): Weight of seeds plant ${ }^{-1}$, weight of pods plant ${ }^{-1}$, straw yield (ton fed ${ }^{-1}$ ) and biological yield (ton $\mathrm{fed}^{-1}$ ) as affected by the interaction between plant spacing and weed control treatments during 2015 and 2016 seasons.

\section{6- Economic of soybean crop:}

Data in Table 10 show that the total cost $\left(\mathrm{L} . \mathrm{E} \mathrm{fed}{ }^{-1}\right)$, which includes land preparation, sowing, fertilization, irrigation, insect control, harvesting and rental cost of land $\mathrm{fed}^{-1}$ $\left(2281\right.$ L.E fed $\left.^{-1}\right)+$ cost of different weed control treatments. The average of gross income L.E fed ${ }^{-1}$ of soybean yield ranged from about 2950.512 to about 7077.708 L.E fed ${ }^{-1}$ with interaction between $\mathrm{P}_{2} \times \mathrm{W}_{9}$ and with interaction between $\mathrm{P}_{1} \times \mathrm{W}_{10}$ as lower and higher values. Moreover, net income of soybean yield $\mathrm{fed}^{-1}$ reached about $4205.300 \quad$ L.E $\quad$ fed $^{-1}$ with interaction between $\mathrm{P}_{1} \times \mathrm{W}_{7}$, while, the lowest values with interaction between $\mathrm{P}_{2} \times \mathrm{W}_{9}$ about 669.512 L.E fed $^{-}$ ${ }^{1}$. The higher net income was due to highest weed control efficiency recorded in these treatments, highest growth attributes and highest seed yield of soybean. Application of weed free $\left(\mathrm{W}_{7}\right)+$ plant spacing $60 \times 4$ $\mathrm{cm}\left(\mathrm{P}_{1}\right)$ recorded higher $\mathrm{B}$ : $\mathrm{C}$ ratio (2.521), and $\mathrm{P}_{1} \times \mathrm{W}_{6}$ (2.456) followed by $\mathrm{P}_{3} \times \mathrm{W}_{7}(2.454)$ than other treatments. These results are in conformity of those of Sylvestre et al. (2013); Thakare et al. (2015) and Rajkumari et al. (2017b). 
Table 10. Effect of plant spacing and weed control treatments on economics of soybean crop as seasons average.

\begin{tabular}{|c|c|c|c|c|c|c|c|}
\hline \multicolumn{2}{|r|}{ Treatments } & \multicolumn{2}{|c|}{ Yield (ton fed fe $^{-1}$} & \multirow{2}{*}{$\begin{array}{l}\text { Total cost } \\
\left(\text { L.E } \text { fed }^{-1}\right)\end{array}$} & \multirow{2}{*}{$\begin{array}{c}\text { Gross } \\
\text { income } \\
\left(\text { L.E fed }{ }^{-1}\right)\end{array}$} & \multirow{2}{*}{$\begin{array}{l}\text { Net income } \\
\left(\text { L.E fed } \text { f }^{-1}\right)\end{array}$} & \multirow{2}{*}{$\begin{array}{l}\text { B: C } \\
\text { Ratio }\end{array}$} \\
\hline $\begin{array}{c}\text { Plant } \\
\text { spacing }\end{array}$ & Weed control treatments & Seed & Straw & & & & \\
\hline \multirow{10}{*}{$\begin{array}{c}P_{1}: \\
60 \times 4 \mathrm{~cm} \\
175.000 \\
\text { Plant fed }^{-1}\end{array}$} & $\mathrm{~W}_{1}$ : Gesagard $(50 \% \mathrm{FW})$ at the rate $1.0 \mathrm{~L}$ & 1.300 & 2.450 & 2513.000 & 6058.200 & 3545.200 & 2.411 \\
\hline & $\mathrm{W}_{2}:$ Fusilade super $(12.5 \% \mathrm{EC})$ at the rate $1.0 \mathrm{~L}$ & 1.025 & 2.301 & 2546.000 & 4840.172 & 2294.172 & 1.901 \\
\hline & $W_{3}$ : Gesagard + Fusilade super & 1.422 & 2.511 & 2778.000 & 6597.684 & 3819.684 & 2.375 \\
\hline & $\mathrm{W}_{4}: \operatorname{Stomp}(50 \% \mathrm{EC})$ at the rate $1.7 \mathrm{~L}$ & 1.410 & 2.352 & 2672.000 & 6518.304 & 3846.304 & 2.439 \\
\hline & $W_{5}:$ Stomp + Fusilade super & 1.424 & 2.550 & 2776.000 & 6613.064 & 3837.064 & 2.382 \\
\hline & $\mathrm{W}_{6}:$ Select-Super $(12.5 \% \mathrm{EC})$ at the rate $1.0 \mathrm{~L}$ & 1.392 & 2.613 & 2641.000 & 6485.148 & 3844.148 & 2.456 \\
\hline & $W_{7}:$ Stomp + 1 hand hoeing & 1.499 & 2.713 & 2761.000 & 6966.300 & 4205.300 & 2.521 \\
\hline & $W_{8}$ : Hand hoeing (2) & 1.417 & 2.531 & 2781.000 & 6579.444 & 3798.444 & 2.366 \\
\hline & $W_{9}$ : Unweeded check & 0.792 & 2.050 & 2281.000 & 3786.712 & 1505.712 & 1.660 \\
\hline & $W_{10}:$ Weed free & 1.523 & 2.715 & 3281.000 & 7070.708 & 3789.708 & 2.155 \\
\hline \multicolumn{2}{|r|}{ Mean of $P_{1}$} & 1.310 & 2.479 & 2743.900 & 6106.548 & 3362.648 & 2.225 \\
\hline \multirow{10}{*}{$\begin{array}{c}P_{2}: \\
60 \times 5 \mathrm{~cm} \\
140.000 \\
\text { Plant } \text { fed }^{-1}{ }_{2}\end{array}$} & $\mathrm{~W}_{1}$ : Gesagard $(50 \% \mathrm{FW})$ at the rate $1.0 \mathrm{~L}$ & 1.272 & 2.401 & 2513.000 & 5558.364 & 3045.364 & 2.212 \\
\hline & $\mathrm{W}_{2}:$ Fusilade super $(12.5 \% \mathrm{EC})$ at the rate $1.0 \mathrm{~L}$ & 1.068 & 2.301 & 2546.000 & 5026.620 & 2480.620 & 1.974 \\
\hline & $\mathrm{W}_{3}$ : Gesagard + Fusilade super & 1.362 & 2.450 & 2778.000 & 6327.032 & 3549.032 & 2.278 \\
\hline & $\mathrm{W}_{4}: \operatorname{Stomp}(50 \% \mathrm{EC})$ at the rate $1.7 \mathrm{~L}$ & 1.335 & 2.351 & 2672.000 & 6192.932 & 3520.932 & 2.318 \\
\hline & $\mathrm{W}_{5}:$ Stomp + Fusilade super & 1.387 & 2.550 & 2776.000 & 6014.032 & 3238.032 & 2.166 \\
\hline & $\mathrm{W}_{6}$ : Select-Super $(12.5 \% \mathrm{EC})$ at the rate $1.0 \mathrm{~L}$ & 1.219 & 2.500 & 2641.000 & 5715.584 & 3074.584 & 2.164 \\
\hline & $W_{7}:$ Stomp + 1 hand hoeing & 1.422 & 2.621 & 2761.000 & 6616.604 & 3855.604 & 2.396 \\
\hline & $W_{8}$ : Hand hoeing (2) & 1.350 & 2.507 & 2781.000 & 6284.804 & 3503.804 & 2.260 \\
\hline & $W_{9}$ : Unweeded check & 0.617 & 1.600 & 2281.000 & 2950.512 & 669.512 & 1.294 \\
\hline & $W_{10}:$ Weed free & 1.468 & 2.614 & 2881.000 & 6814.856 & 3933.856 & 2.365 \\
\hline \multicolumn{2}{|r|}{ Mean of $P_{2}$} & 1.250 & 2.390 & 2743.900 & 5831.080 & 3088.080 & 2.126 \\
\hline \multirow{10}{*}{$\begin{array}{c}P_{3}: \\
70 \times 4 \mathrm{~cm} \\
150.000 \\
\text { Plant fed }^{-1}\end{array}$} & $\mathrm{~W}_{1}$ : Gesagard $(50 \% \mathrm{FW})$ at the rate $1.0 \mathrm{~L}$ & 1.227 & 2.451 & 2513.000 & 5741.844 & 3228.844 & 2.285 \\
\hline & $\mathrm{W}_{2}:$ Fusilade super $(12.5 \% \mathrm{EC})$ at the rate $1.0 \mathrm{~L}$ & 1.173 & 2.411 & 2546.000 & 5500.820 & 2954.820 & 2.161 \\
\hline & $W_{3}:$ Gesagard + Fusilade super & 1.247 & 2.714 & 2778.000 & 5856.600 & 3078.600 & 2.108 \\
\hline & $\mathrm{W}_{4}: \operatorname{Stomp}(50 \% \mathrm{EC})$ at the rate $1.7 \mathrm{~L}$ & 1.364 & 2.352 & 2672.000 & 6318.848 & 3646.848 & 2.369 \\
\hline & $\mathrm{W}_{5}:$ Stomp + Fusilade super & 1.450 & 2.513 & 2776.000 & 6719.436 & 3943.436 & 2.421 \\
\hline & $\mathrm{W}_{6}$ : Select-Super $(12.5 \% \mathrm{EC})$ at the rate $1.0 \mathrm{~L}$ & 1.224 & 2.511 & 2641.000 & 5739.156 & 3098.156 & 2.173 \\
\hline & $W_{7}:$ Stomp + 1 hand hoeing & 1.459 & 2.612 & 2761.000 & 6775.488 & 4014.488 & 2.454 \\
\hline & $\mathrm{W}_{8}$ : Hand hoeing (2) & 1.427 & 2.501 & 2781.000 & 6617.644 & 3836.644 & 2.380 \\
\hline & $\mathrm{W}_{9}$ : Unweeded check & 0.724 & 1.912 & 2281.000 & 3468.128 & 1187.128 & 1.520 \\
\hline & $W_{10}:$ Weed free & 1.487 & 2.650 & 2881.000 & 6903.432 & 4022.432 & 2.396 \\
\hline \multicolumn{2}{|r|}{ Mean of $P_{3}$} & 1.278 & 2.453 & 2743.900 & 5963.324 & 3220.324 & 2.174 \\
\hline \multirow{10}{*}{$\begin{array}{c}P_{4}: \\
70 \times 5 \mathrm{~cm} \\
120.000 \\
\text { Plant fed }^{-1}\end{array}$} & $\mathrm{~W}_{1}$ : Gesagard $(50 \% \mathrm{FW})$ at the rate $1.0 \mathrm{~L}$ & 1.265 & 2.302 & 2513.000 & 5990.984 & 3367.984 & 2.384 \\
\hline & $\mathrm{W}_{2}:$ Fusilade super $(12.5 \% \mathrm{EC})$ at the rate $1.0 \mathrm{~L}$ & 1.075 & 2.254 & 2546.000 & 5048.888 & 2508.888 & 1.983 \\
\hline & $\mathrm{W}_{3}$ : Gesagard + Fusilade super & 1.294 & 2.451 & 2778.000 & 6032.356 & 3254.356 & 2.171 \\
\hline & $\mathrm{W}_{4}: \operatorname{Stomp}(50 \% \mathrm{EC})$ at the rate $1.7 \mathrm{~L}$ & 1.308 & 2.350 & 2672.000 & 6075.688 & 3403.688 & 2.274 \\
\hline & $\mathrm{W}_{5}:$ Stomp + Fusilade super & 1.384 & 2.500 & 2776.000 & 6431.024 & 3655.024 & 2.317 \\
\hline & $\mathrm{W}_{6}:$ Select-Super $(12.5 \% \mathrm{EC})$ at the rate $1.0 \mathrm{~L}$ & 1.192 & 2.450 & 2641.000 & 5583.276 & 2942.276 & 2.114 \\
\hline & $\mathrm{W}_{7}:$ Stomp +1 hand hoeing & 1.400 & 2.550 & 2761.000 & 6509.000 & 3748.000 & 2.357 \\
\hline & $W_{8}$ : Hand hoeing (2) & 1.372 & 2.501 & 2781.000 & 6379.164 & 3598.164 & 2.294 \\
\hline & $W_{9}$ : Unweeded check & 0.647 & 1.502 & 2281.000 & 3063.736 & 782.736 & 1.343 \\
\hline & $W_{10}:$ Weed free & 1.410 & 2.602 & 2881.000 & 6561.304 & 3680.304 & 2.277 \\
\hline \multicolumn{2}{|r|}{ Mean of $\mathrm{P}_{4}$} & 1.235 & 2.346 & 2743.900 & 5758.472 & 3015.472 & 2.099 \\
\hline
\end{tabular}

\section{Conclusion}

From this study, it could be recommended that weed control by Stomp 50\% EC+one hand hoeing, Gesagard 50\% FW + Fusilade super $(12.5 \% \mathrm{EC})$ and hand hoeing twice and sowing soybean plants var. Giza 111 by 175000 plant $\mathrm{fed}^{-1}(60 \times 4 \mathrm{~cm}$ between plants) produce the highest grain yield and quality under the environmental conditions of Minia Governorate, Egypt.

\section{References}

Acikgoz, E.; Sincik, M.; Karasu, A.; Tongel, O. and Wietgrefe, G. (2009). Forage soybean production for seed in mediterranean environments. Field Crop Recearch 110: 213-218.

Andres, F.; Alvadi, A.B. and Flavia, W. (2018). Soybean agronomic performance in response to seeding rate and phosphate and potassium fertilization. RevistaBrasileira de 
Engenharia Agricola e Ambiental, 22(3): 151-157.

Agriculture Statistical (2015). Summer $\&$ Nile Crops. Agriculture Statistical and Economic Affairs Sector, $2^{\text {nd }}$ Ed., Ministry of Agriculture and Land Reclamation, Egypt.

Akond, A.G.M.; Bobby, M.; Bazzelle, R.; Clark, W.; Kantartzi, K.M. and Kaddem. A. (2013). Effect of two row space on several agronomic traits in soybean [Glycine $\max (\mathrm{L}$.) Merr.]. Ttlas J. of Plant Biology $1(2): 18-23$.

Akter, N.; Ruhul Amin, A.K.M.; Masum, S.M.andHaque, M.N. (2016). Effect of sowing dates and weed control methods on yield components of soybean [Glycine max L. Merrill.].Pak. J. Weed Sci. Res., 22 (4):527-541.

A.O.A.C. (1990). Official Methods of Analysis of Association of Official Agriculture Chemists. 12th Edition, Washington, D.C.

Ariunaa, O.; Otgonsuren, M. and Bayarsukh, N. (2016). Effect of chemical weed control of soybean (Glycine $\max$ L.) field in Mongolia. Int. J. Adv. Res. Bio. Sci., 3(1): 192-198.

Aradhana Ball; Bazaya, B.R.; Lekh Chand and Swami, S. (2016). Weed management in soybean (Glycine max L.). The Bioscan 11 (1): 255-257.

Asmaa, M. Hamoda; Sary, G.A.; ELsayedShokr and Roshdy, A. (2017). Effect of some weed control treatments and plant density on two soybean varieties and associated weeds. Annals of Agric. Sci., Moshtohor, 55(1): 1-10.

Balyan, R.S. and Malik, R.K. (2003). Effect of post-emergence herbicide for weed management in soybean (Glycine $\max$ L.)Indain J. Weed Sci., 35(1\&2): 62-66.

Bhagirath, S.C. and Jhoan L. Opena (2014). Effect of plant spacing on growth and grain yield of soybean. American J. Plant Sci., 4: 20112014.

Caliskan, S.M.; Aslan, M.; Uremis, I. and Caliskan, M.E.(2007). The effect of row spacing on yield and yield components of full season and double cropped soybean. Turkish J Agric. \& Forestry 31: 147-154.

Cassileth,B.r. and Vickers, A.J. (2003). Soy: an anticancer agent in wide use despite some troubling data. Cancer Invest. 21(5): 817-818.

Chandraker, A.K. and Paikra, P.R. (2015). Effect of integrated weed management on weed dynamics of soybean [Glycine max (L.) Merrill] under Chhattisgarh plain. Indian J. Agric. Res., 49(1): 53-58.

Chaunhan, B.S. and Opena, J.L. (2013). Effect of plant spacing on growth and grain yield of soybean. American J. Plant Sci., 4: 2011-2014.

El-Far, E.A.; El-Nagar, G.R.; Salib, S.R. and Kalafalla, M.A.B. (2016). Response of some soybean genotypes to planting date and plant density. Assiut J. Agric. Sci., 47(5): 1-11.

El-Gizawy, N.KH.B.; Fadlallah, A.M.A. Hassanein and Soliman, I.E. (2012). Estimation of the critical period for weed control in soybean (Glycin $\max$ L.) as influenced by plant density. J. Plant Production, Mansoura Univ., 3(9): 2375-2394.

Galal, A.H. (2004). Effect of weed control treatments and hill-spacing on soybean and associated weeds. Acta Agronomica Hungarica, 52(1): 81-93.

Gill, G.S. and Vijay Kumer, K. (1969). "WeedIndex" A new method for reporting weed control trails. Indian J. of Agron., 14:96-98.

Gomez, K.A. and Gomez, A.A. (1984). Statistical Procedures for Agriculture Research. A Wiley-Inter Sci- 
ence Publication, John Wiley and Sons, Inc. New York, USA.

Gulluoglu,L.; Bakal, H.; EL-Sabagh, A. and Arioglu, H. (2016). The effects of twin-row planting pattern and plant population on seed yield components of soybean at late double-cropped planting in Cukurova Region. Turk J. Field Crops 21(1): 59-65.

Gulluoglu, L.; Bakal, H.; EL-Sabagh, A. and Arioglu, H. (2017). Soybean managing for maximize production: Plant population density affects seed yield and some agronomical traits in main cropped soybean production. J. of Experimental Biology \& Agric. Sci., 5(1): 31-37.

Hassan,A.A.A. (2015). Study of some herbicides and plant density on the growth and soybean yield. Research J. of Pharmaceutical, Biological and Chemical Sci., 6(1): 115-126.

Heady, E.O. and Dillon, J.L. (1961). Agricultural production function. Library of Congress catalog card number: 60-11128, Iwoa State University Press.

Hosseini, S.Z.; Firouzi, S.; Aminpanah, H. and Sadeghnejhad, H.R. (2016). Effect of tillage system on yield and weed populations of soybean (Glycine $\max$ L.). An. Acad. Bras. Cienc., 88(1): 377-384.

Ibrahim, S.A. and Kandil, H. (2007). Growth, yield and chemical constituents of soybean (Glycin max L.) plants as affected by plant spacing under different irrigation intervals. Res. J. Agric. \& Biol. Sci. 3(6):657-663.

Jadhav, J.B. (2007). Effect of herbicides and cropweed competition on physiological aspects in soybean (Glycine max L.). Master thesis, Univ. of Agric. Sci. Dharwad.
Kanase, A.A.; Mendhe, S.N.; Khawale V.S.; Jarande, N.N. and Mendhe, J.T.(2006). Effect of integrated nutrient management and weed biomass addition on growth and yield of soybean. J.Soils Crops. 16(1): 236-239.

Knezevic, S.Z.; Evans, S.P. and Mainz, M. (2003). Row spacing influences the critical timing for weed removal in soybean (Glycine max). Weed Technology, 17(4): 666-673.

Kulal, D.A.; Dhaigude, G.S. and Adat, S.S. (2017). Evaluation of efficacy of post-emergence herbicides for weed control in soybean under Marathwada region. Internat. $\mathrm{J}$. Agric.Sci., 13(1): 53-55.

Lamptey, S.; Yeboah, S.; Sakodie, K. and Berdjour, A. (2015).Growth and yield response of soybean under different weeding regimes. Asian J. Agric. and Food Sci., 3(2): 155-163.

Manjunath, N.C. and Hosmath, J.A. (2016). Effect of sequential application on weed dynamics and yield of soybean [Glycine max (L.) Merrill]J.Farm Sci.,29(2):187-189.

Matsuo, N.; Tetsuya, Y.; Yoshitake, T.; Koichiro, F. and Makita, $\mathrm{H}$. (2018). Effect of plant density on growth and yield of new soybean genotypes grown under early planting condition in southwestern Japan. Plant Production Science, P: 1-10

Nandini Devi, K.; Lenin Singh, K.H.; AranghaMangang, C.N. and Brajendra Singh, N. (2016). Effectof weed control practices on weed dynamics, yield and economics of soybean [Glycine $\max$ (L.) Merrill]. Legume Research, 39 (6): 995-998.

Pandya, N.; Chouhan, G.S. and Nepalla, V. (2005). Effect of varieties, crop geometries and weed management on nutrient uptake by soybean 
(Glycine $\max$ L.) and associated weeds. Indian J. Agron., 50(3): 218-220.

Paudel, P.; Singh, R.S.; Pandey, I.B. and Prasad, S.S. (2017). Effect of different weed management practices on weed dynamic, yield and economics of soybean production. Azarian J. Agric., 4(2): 54-59.

Peer, F.A.; Hassan, B.; Lone, B.A.; Qayoom, S.; Ahmad, L. and Khanday, B.A. (2013). Effect of weed control methods on yield and yield attributes of soybean. Afr. J. Agric. Res., 8(48): 6135-6141.

Rajkumari; Khaswan, S.L.; Kumar, A.; Kumar, K. and Thori, S.S. (2017a). Effect of different tillage practices and weed management on weed dynamics, productivity and quality of soybean [Glycine max (L.) Merrill]. Internat. J. Chemical Studies.5(4): 1695-1697.

Rajkumari; Khaswan, S.L.; Kumar, A.; Kumar, K. and Thori, S.S. (2017b). Influnce of different tillage and weed management practices on growth parameters and chlorophyll content of soybean in sub-humid Rajasthan. J. Pharmacognosy \& Phytochemistry 6(4): 1793-1796.

Saitoh, K. (2011). Effect of row-spacing and plant density on podding and yield performance of early soybean cultivar "Enrei" with reference to raceme order. In: El-Shemy, $\mathrm{H}$ (Ed.). Agric. \& Biological Sci. Soybean Physiology and Biochemistry. pp: $275-288$.

Sawant, A.C. and Jadav, S.N. (1985). Efficiency of different herbicides for weed control in transplanted rice in Konkan. Indian Journal of Weed Science, 17(3): 35-39.

Seadh, S.E. and Abido, W.A.E. (2013). How soybean cultivars canopy affect yield and quality. J. of Agron.: 1-7.
Shaikh, A.A., Desal, M.M., Shinde, S.B. and Tambe, A.D. (2010). Yield and quality of soybean [Glycine $\max$ (L.) Merrill] as influenced by integrated weed management. Internat. J. Agric. Sci., 6(2):534-536.

Singh, M.; Jagdeesh, M.; Verma, A.K.; Chouhan, S.S. and Gour, G.L. (2016). Assessment of weed control treatments on yield of soybean (Glycine $\max$ L.) at tribal jhabua hills zone of Madhya Pradesh. Inter. J. Agric. Sci. and Res., 6(6): 23-28.

Singh, Neelu (2015). Effect of herbicides on physiological parameters, growth, yield andqualtiy of soybean (Glycine $\max$ L.). Master thesis, Jabalpur, Madhya Pradesh.

Singh, Pratap, V.; Singh, S.P.; Kumar, A.; Banga, A.; Tripathi, N. and Rekha (2014). Performance of quizalofop-p-ethyl 5\% EC against weeds and yield of soybean. Soybean Research, 12(2): 120-126.

Soliman, I.E.; Morsi, A.R. and Azza, E.K. (2015). Effect of competitive abilities of some soybean genotypes, plant density and weed control treatments on soybean (Glycine $\max$ L.) and its associated weeds. J. Plant Production, Mansoura Univ., 6(8): 1413-1429.

Sylvestre, H.; Kalyana Murthy, K.N.; Shankaralingappa, B.C.; Sanjay, M.T. and Ramachandra, C. (2013). Effect of pre and post-emergence herbicides on weed dynamics, growth and yield of soybean (Glycine $\max$ L.). Adv. Appl . Sci. Res., 4(4): 72-75.

Thakare, S.S.; Deshmukh, J.P.; Shingrup, P.V.; Pawar, P.M. and Ghlop, A.N. (2015). Efficacy of different new herbicides against weed flora in soybean (Glycine $\max$ L.). Plant Archives 15(1): 217-220. 


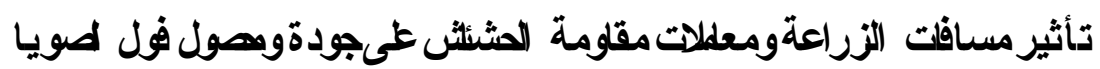

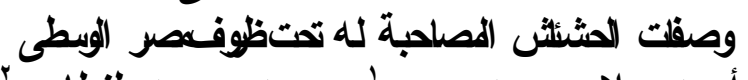

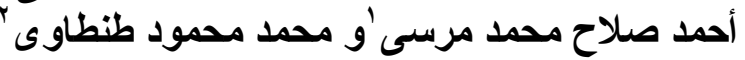

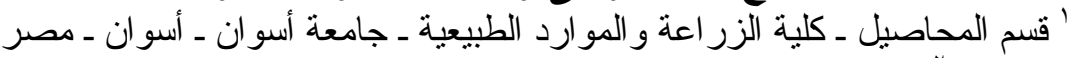

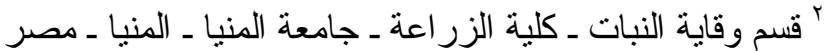

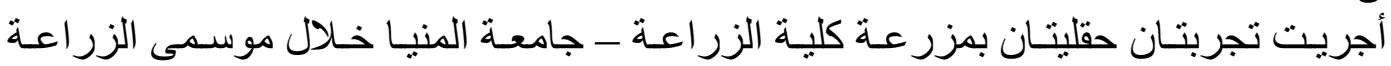

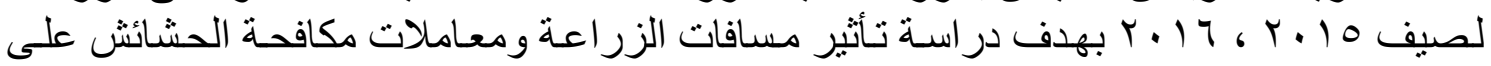

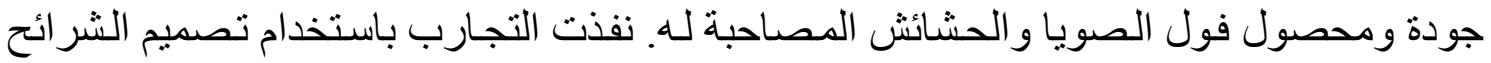

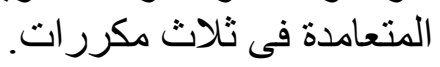

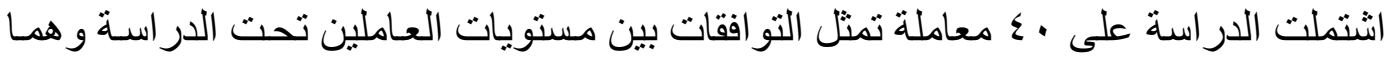

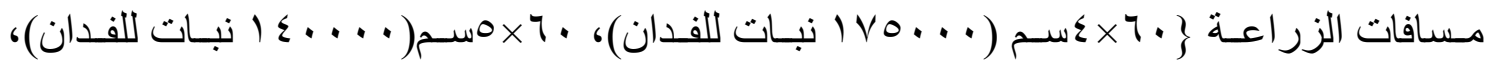

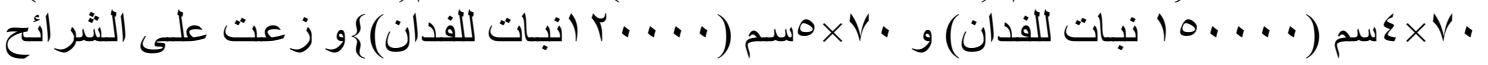

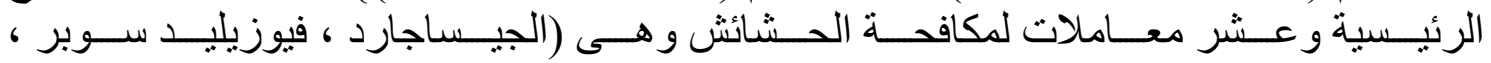

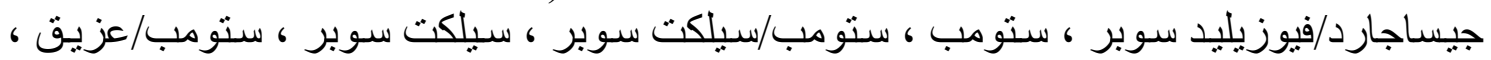

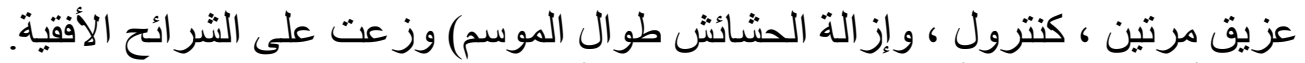

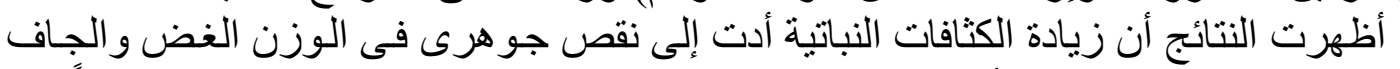

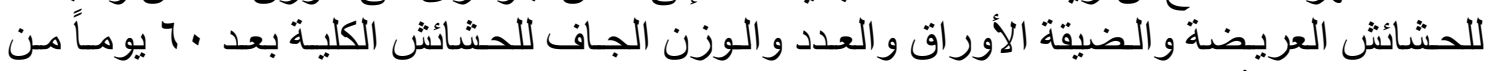

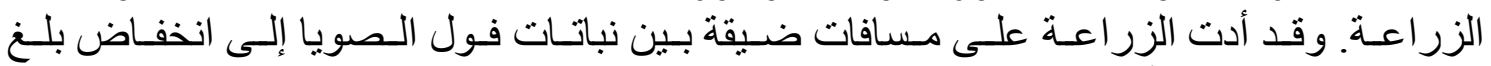

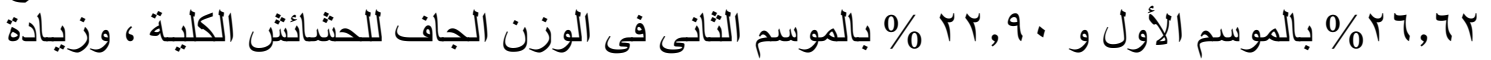

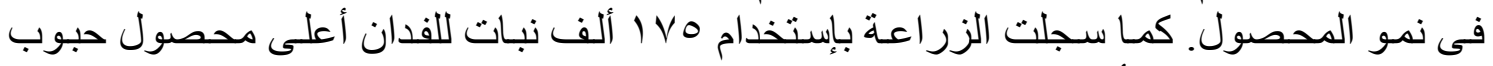

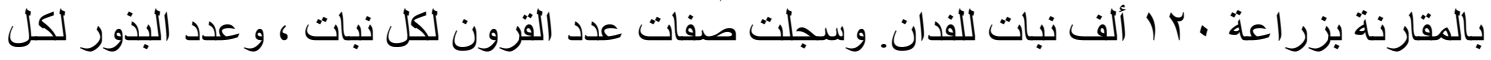

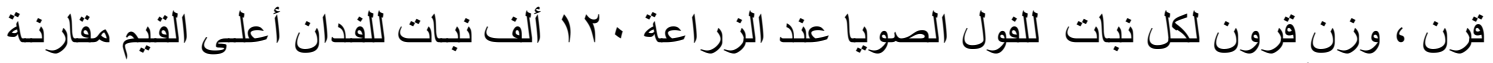

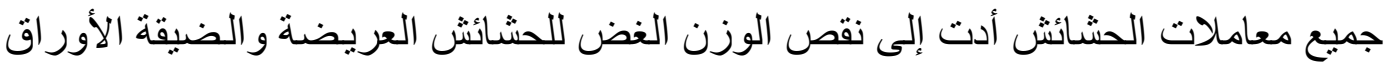

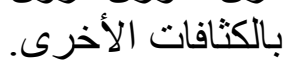

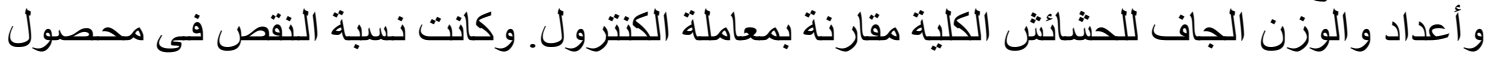

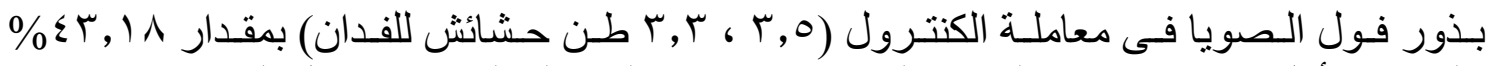

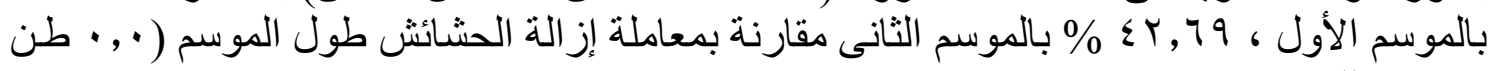

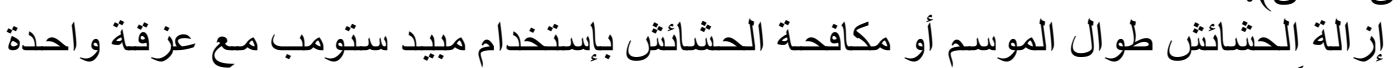

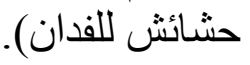

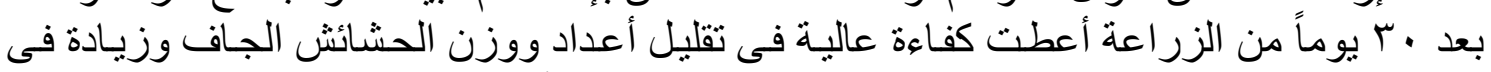

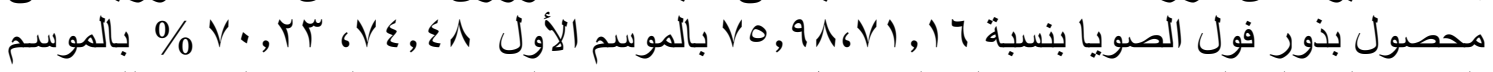

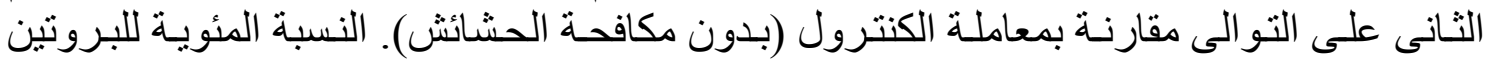

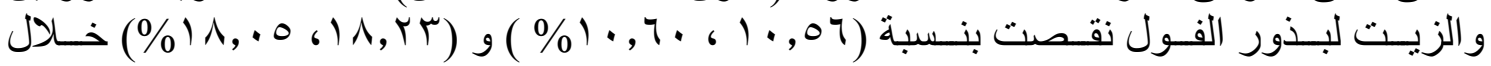

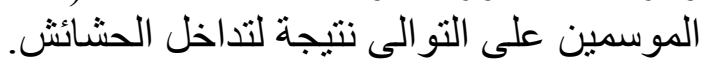

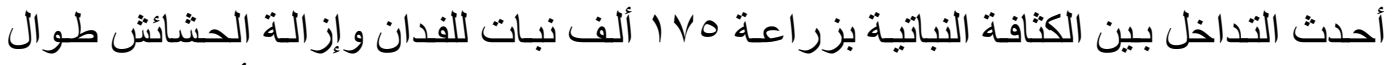

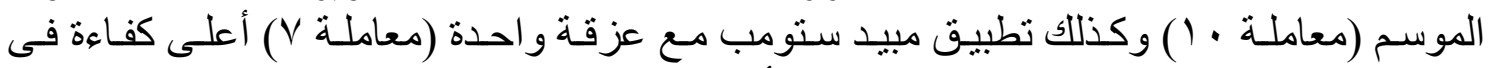

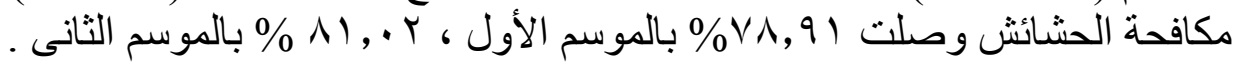

